\title{
Proteomic based approach for characterizing 4-hydroxy-2-nonenal induced oxidation of buffalo (Bubalus bubalis) and goat (Capra hircus) meat myoglobins
}

Naveena B. Maheswarappa ${ }^{1 *}$, K. Usha Rani ${ }^{1}$, Y. Praveen Kumar ${ }^{1}$, Vinayak V. Kulkarni ${ }^{1}$ and Srikanth Rapole ${ }^{2}$

\begin{abstract}
Background: Myoglobin (Mb) is a sarcoplasmic heme protein primarily responsible for meat color and its chemistry is species specific. 4-hydroxy-2-nonenal (HNE) is a cytotoxic lipid derived aldehyde detected in meat and was reported to covalently adduct with nucleophilic histidine residues of $\mathrm{Mb}$ and predispose it to greater oxidation. However, no literature is available on characterization of lipid oxidation induced oxidation of Indian water buffalo (Bubalus bubalis) and goat (Capra hircus) myoglobins.

Methods: Present study characterize the Mb extracted from water buffalo and goat cardiac muscles using two-dimensional gel electrophoresis (2DE), OFFGEL electrophoresis and mass spectrometry (MS). Purified buffalo and goat bright red oxymyoglobin were reacted with HNE in-vitro at physiological pH (7.4) and temperature $\left(37^{\circ} \mathrm{C}\right)$ conditions and the formation of oxidised brown metmyoglobin was measured. The Mb-HNE adducts were detected using MALDI-TOF MS, whereas specific sites of adduction was determined using ESI-QTOF MS/MS.

Results: Purified buffalo and goat Mb samples revealed a molecular mass of 17,043.6 and 16,899.9 Daltons, respectively. The 2DE analysis exhibited 65 (sarcoplasmic protein extract) and 6 (pure Mb) differentially expressed $(P<0.05)$ protein spots between buffalo and goat samples. OFFGEL electrophoresis revealed an isoelectric point of 6.77 and 7.35 respectively, for buffalo and goat Mb's. In-vitro incubation of HNE with bright red buffalo and goat oxymyoglobin's at pH 7.4 and $37^{\circ} \mathrm{C}$ resulted in pronounced $(P<0.05)$ oxidation and formation of brown metmyoglobin. MALDI-TOF MS analysis of Mb-HNE reaction mix revealed covalent binding (via Michael addition) of 3 and 5 molecules of HNE with buffalo and goat Oxy-Mb's, respectively. ESI-QTOF MS/MS identified seven and nine histidine (HIS) residues of Mb that were readily adducted by HNE in buffalo and goat, respectively.

Conclusion: The study demonstrated better redox stability of buffalo Mb than goat Mb. Our findings confirm the hypothesis that relative effect of HNE was greater for Mb's with $12 \pm 1$ HIS residues than Mb's with 9 HIS residues and helps meat processors in developing species-specific processing strategies to reduce the color variability.
\end{abstract}

Keywords: Myoglobin-HNE adduction, Redox instability, OFFGEL electrophoresis, 2-Dimensional gel electrophoresis, Mass spectrometry

\footnotetext{
* Correspondence: naveenlpt@rediffmail.com

${ }^{1}$ National Research Centre on Meat, Chengicherla, Hyderabad, Telangana

500092, India

Full list of author information is available at the end of the article
} International License (http://creativecommons.org/licenses/by/4.0/), which permits unrestricted use, distribution, and reproduction in any medium, provided you give appropriate credit to the original author(s) and the source, provide a link to the Creative Commons license, and indicate if changes were made. The Creative Commons Public Domain Dedication waiver (http://creativecommons.org/publicdomain/zero/1.0/) applies to the data made available in this article, unless otherwise stated. 


\section{Background}

India is the largest producer and exporter of water buffalo (Bubalus bubalis) meat in the world and accounts for $23.5 \%$ of global bovine meat exports [1]. Indian water buffalo meat is considered lean with higher protein and ash content relative to cattle meat (beef) [2]. Owing to its healthier properties, buffalo meat is emerging as an important red meat source in several Middle-east, South-east and European countries. India is the second largest producer of goat (Capra hircus) meat next to China. Goat meat is a popular red meat in many regions of the world and the consumer preference of goat meat is almost universal depending on cultural traditions and social and economic conditions [3]. Buffalo meat is darker compared to beef and the darkness is attributed to higher myoglobin $(\mathrm{Mb})$ content $(5.0 \mathrm{mg} / \mathrm{g})$ [4]. Dosi et al. (2006) have studied the primary structure of buffalo $\mathrm{Mb}$ using a combined approach of Edman degradation and MALD-TOF mass spectrometry and found a difference of three amino acids out of 153 compared to beef $\mathrm{Mb}$ [5]. These authors have also studied the stability, autoxidation and percent metmyoglobin formation in beef and buffalo Mb's and reported identical results between them. Another important livestock species, goat was reported to share $98.7 \%$ sequence similarity with sheep than with buffalo which has got $95.4 \%$ sequence similarity. Goat meat was reported to be darker, more red and have higher sarcoplasmic protein content than sheep meat [6]. Primary structure of goat $\mathrm{Mb}$ was determined by Suman et al. (2009) who reported that goat Mb shared $98.7 \%$ similarity with sheep $\mathrm{Mb}$ and the distal (64) and proximal (93) histidines responsible for coordinating the heme group and reversible binding of oxygen are conserved in goat $\mathrm{Mb}$, similar to other meat-producing livestock [7].

Molecular properties and overall structure of the $\mathrm{Mb}$ protein from different species have been reported to be very similar although there are differences in the amino acid composition and the exact length of the polypeptide chain. Primary structure of $\mathrm{Mb}$ influences meat color stability via mechanisms such as autoxidation, heme retention, structural stability, thermostability, and oxygen affinity [8]. Oxidation of ferrous oxymyolobin (Oxy-Mb) to ferric metmyoglobin (Met-Mb) will result in conversion of desirable bright red color of the meat into undesirable brown color [9]. Several researchers have demonstrated that myoglobin oxidation and lipid oxidation are interrelated and the acceleration of one will exacerbate the other [9-12]. These researchers have demonstrated acceleration of heme protein oxidation in the presence of unsaturated aldehydes generated by free radical-induced lipid peroxidation of polyunsaturated fatty acids. 4-Hydroxy-2-nonenal (HNE) is an $\alpha, \beta-$ unsaturated aldehyde derived from the oxidation of $\omega-6$ polyunsaturated fatty acids and has been reported in meat [13]. It was reported to involve in the onset and progression of many pathological conditions such as cardiovascular and neurodegenerative diseases due to its ability to react with the nucleophilic sites of proteins and peptides to form covalently modified biomolecules [14]. Because of high reactivity of HNE with proteins, researchers have concluded the possibility of using HNEadducted proteins as markers for oxidative damage [15]. HNE was also reported to induce redox instability of Mb's from horse, cattle, pig, sheep, deer, chicken, turkey, emu and ostrich meats under different conditions and in all cases Oxy-Mb oxidation was promoted [9, 10, 12, 16-18]. These studies suggest that, HNE accelerates Oxy-Mb oxidation in-vitro by covalent modification at histidine residues. Using LC-MS/MS analysis Alderton et al. (2003) identified six histidine residues of beef $\mathrm{Mb}$ that were readily adducted by HNE, including the proximal (HIS 93) and distal (HIS 64) histidines associated with the heme group at $\mathrm{pH} 7.4$ and $37{ }^{\circ} \mathrm{C}$ [10]. However, Suman et al. (2007) demonstrated the adduction of HNE with three and seven histidine residues in porcine and beef Mb's under similar conditions [12]. These authors have hypothesized that, the lesser number of nucleophilic HIS residues and their specific locations in porcine $\mathrm{Mb}$ are responsible for the greater redox stability of porcine $\mathrm{Mb}$ in the presence of lipid oxidation products relative to beef. They further concluded that, preferential HNE adduction at proximal HIS 93 was observed only in bovine Oxy-Mb and hence lipid oxidation induced $\mathrm{Oxy}-\mathrm{Mb}$ oxidation was potentially more critical in beef than pork. Yin et al. (2011) studied the HNE induced oxidation of Oxy-Mb's from seven different meat animals and concluded that, the relative effect of HNE was greater for Mb's that contained $12 \pm 1$ HIS residues than for those that contained nine HIS residues [18]. All these researchers suggested a species specific effect of $\mathrm{HNE}$ on $\mathrm{Mb}$. In the present study we propose to characterize the Mb-HNE adductions in two ruminant species viz, water buffalo and goat with 13 and $12 \mathrm{HIS}$ residues in their Mb, respectively.

Almost all the studies related to meat color have used liquid chromatography-mass spectrometry (LC-MS) based tools to characterize the primary structure of $\mathrm{Mb}$, to understand the lipid oxidation induced oxidation of Oxy$\mathrm{Mb}$ and to determine the redox instability of mutant sperm whale $\mathrm{Mb}[5,9,10,19]$. Investigations have documented the contribution of sarcoplasmic proteome on muscle-specificity in beef color [20, 21]. However, to our knowledge no studies have been reported on use of twodimensional gel electrophoresis (2DE) coupled with mass spectrometry to characterize purified Mb's especially from water buffalo and goat meats. Further, to our knowledge HNE induced oxidation of buffalo and goat Mb's and identification of specific amino acids with which it reacts was not previously reported. Therefore, our objectives 
were 1) to characterize the Mb using 2DE, OFFGEL electrophoresis and mass spectrometry from two important emerging meat animals, buffalo and goat and 2) to investigate the potential binding of HNE to buffalo and goat meat Mb's and determine how it affects redox stability under different temperature and $\mathrm{pH}$ conditions. The present study is the first to characterize the livestock Mb's using 2DE and OFFGEL electrophoresis.

\section{Results and discussion}

\section{Purification of buffalo and goat Mb's}

Isolation and purification of beef, pork, sheep, turkey and chicken myoglobins (Mbs) either from skeletal, heart or smooth muscles using ammonium sulfate precipitation and gel filtration has been reported by different authors $[7,12,16,18]$. The extraction and purification of $\mathrm{Mb}$ from buffalo and goat is minimally investigated and to our knowledge only two papers are available in the literature for buffalo and goat $\mathrm{Mb}$ extraction and characterization $[5,7]$. Dosi et al. (2006) have extracted buffalo Mb in Milli $\mathrm{Q}$ water and further purified through dialysis, Sephacryl S-100 column chromatography followed by Diethylaminoethyl (DEAE) anion exchange chromatography [5]. Goat $\mathrm{Mb}$ was extracted and purified by Suman et al. (2009) using the modified procedure of Faustman and Phillips (2001) [7, 22]. These authors have used 50\% ammonium sulfate saturation in place of $70 \%$ as originally suggested by Faustman and Phillips (2001) [22]. In the present study, we have successfully extracted and purified both buffalo and goat Mb's as per the procedure suggested by Faustman and Phillips (2001) with 70\% ammonium sulfate precipitation and gel filtration chromatography using Sephacryl S-200 HR [22]. Purification of ammonium sulfate precipitated and dialyzed Mb on Sephacryl S-200 HR gel-filtration column revealed two major peaks at $A_{540}$ for buffalo (Fig. 1a) and goat (Fig. 1b). This elution pattern suggests clear separation of hemoglobin and $\mathrm{Mb}$ on gel filtration column. Hemoglobin $(\sim 64 \mathrm{kDa})$ elutes first followed by $\mathrm{Mb}(\sim 17 \mathrm{kDa})$ and these findings confirm with our earlier reports for chicken and turkey Mb's [16].

\section{SDS-PAGE and two-dimensional gel electrophoresis (2DE) of buffalo and goat Mb's}

The SDS-PAGE of pooled fractions from second peak which is supposed to be $\mathrm{Mb}$, consistently revealed the presence of single band at approximately $17 \mathrm{kDa}$ level in both buffalo and goat (Fig. 2) samples. Dosi et al. (2006) also reported a single protein band for purified buffalo $\mathrm{Mb}$ on SDS-PAGE without any detectable contaminating protein bands [5]. Our findings confirm that buffalo and goat Mb's can be purified using different ammonium sulphate precipitation, dialysis, filtration and gel filtration chromatography steps as suggested by Faustman and Phillips (2001) [22]. To further check the purity of
$\mathrm{Mb}, 2 \mathrm{DE}$ of sarcplasmic extract and the purified Mb's from buffalo and goat was carried out. Wu et al. (2016) used 2DE and tandem MS to differentiate sarcoplasmic proteome of Longissimus lumborum (LL) and Psoas major (PM) muscles of Chinese Luxi yellow cattle and identified the proteins mainly involved in glycolytic metabolism which contributed to better meat color stability in LL compared to PM [23]. In the present study, sarcoplasmic proteome extract and gel-filtered purified $\mathrm{Mb}$ from buffalo and goat were characterized using 2DE. The 2DE was done to separate differentially expressed sarcoplasmic proteins mainly consist of myoglobin, hemoglobin, cytochrome and wide variety of endogenous enzymes that are associated with meat color. The analysis of 2DE gels revealed separation of 508 and 563 spots respectively, in buffalo and goat sarcoplasmic extracts (Fig. 3a and c). The class analysis table by analysis of variance (ANOVA) of buffalo and goat sample gels indicated 65 differential spots $(p<0.05)$ which had protein spot expression of 1.5 fold or more between them. Variation in spot intensity/abundance was consistently observed across three gels each for buffalo and goat samples. Joseph et al. (2012) observed a total of 180 protein spots for sarcoplasmic protein extract from beef Longissimus lumborum and indicated 17 differentially abundant protein spots in comparison to Psoas major muscle [21]. Purified Mb's revealed 19 and 20 spots, respectively for buffalo (Fig. 3b) and goat (Fig. 3d) samples with six spots being differentially expressed $(p<0.05)$ between them. The over-abundance of spots in goat sarcoplasmic proteins might be due to post-translational modification of some proteins at a greater degree in goat than in buffalo which may compromise color stability. Sarcoplasmic proteome governs different biochemical processes influencing meat color stability and their interactions with myoglobin are critical to meat color. Present study established the differential abundance of sarcoplasmic proteome between buffalo meat and goat meats. A beef color stability variation due to differences in sarcoplasmic proteome was reported by Joseph et al. (2012) [21]. Differential analysis of sarcoplasmic proteome using image analyses of the Coomassie-stained 2DE gels was reported to contain twelve differentially abundant protein spots in color-stable and color-labile beef longissimus muscles [20]. Our findings suggest significant variation in sarcoplasmic proteome between buffalo and goat samples. Eventhough, purification of buffalo and goat Mb's using gel-filtration resulted in single band at $17 \mathrm{kDa}$ in SDS-PAGE anlaysis, the 2DE revealed few other contaminating proteins with very little intensity/ abundance. However, in both buffalo and goat 2DE gels, single large $\mathrm{Mb}$ fraction was observed at same location. This spot was further analysed using peptide mass fingerprinting (PMF) for confirmation of $\mathrm{Mb}$. 


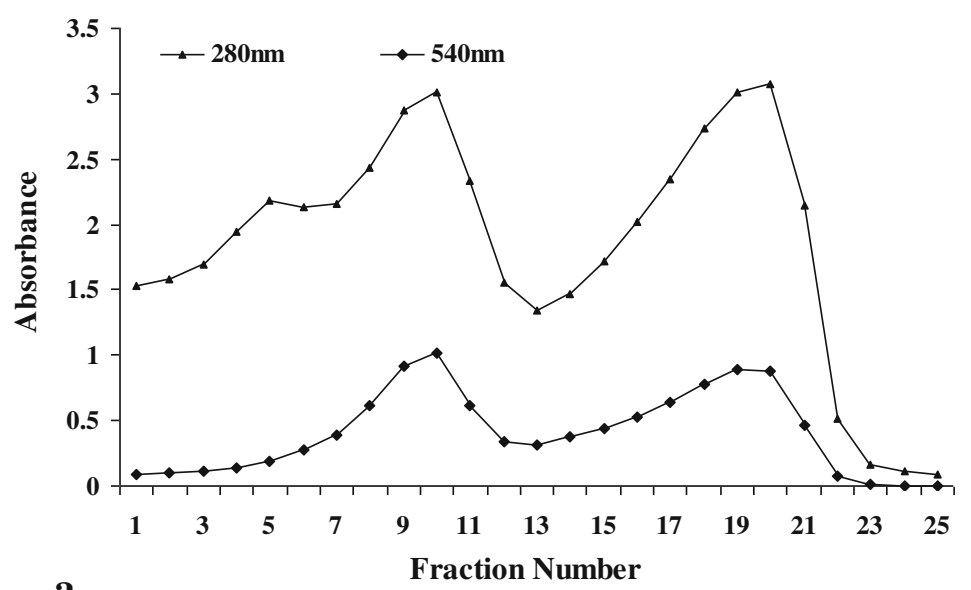

a

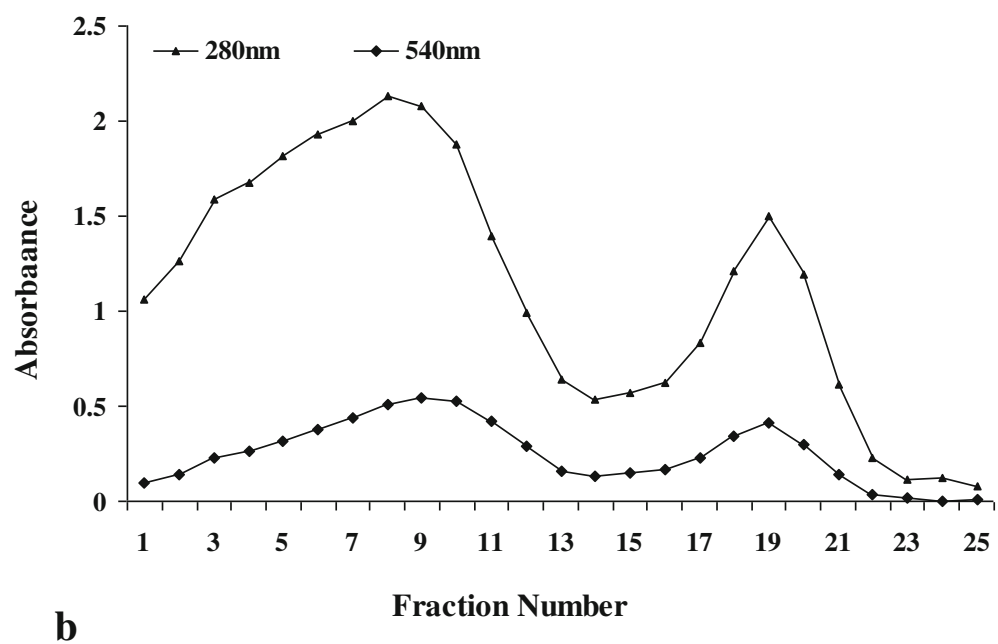

Fig. 1 Elution profile of (a) buffalo and $\mathbf{b}$ goat cardiac myoglobin from Sephacryl S-200 HR gel filtration chromatography. The column was equilibrated and eluted with $5 \mathrm{mM}$ Tris- $\mathrm{HCl}+1 \mathrm{mM}$ EDTA buffer, $\mathrm{pH} 8.0$ at a flow rate of $0.1 \mathrm{~mL} / \mathrm{min}$

\section{Determination of molecular mass and peptide mass fingerprinting using MALDI-TOF MS}

Mass spectrometry analysis was performed only for the purified Mb's to determine molecular mass and to confirm their identity through PMF. The MALDI-TOF MS analysis of intact buffalo $\mathrm{Mb}$ revealed the mass of 17043.6 Daltons (Fig. 4a) which is 97.6 Daltons more than beef $\mathrm{Mb}$ [24]. The MS analysis of goat Mb revealed a mass of 16899 Daltons (Fig. 4b) which is 24 Daltons less than sheep Mb [25]. The observed molecular mass for buffalo $\mathrm{Mb}$ in the present study is 9.6 Daltons higher than the report of Dosi et al. (2006) for Italian water buffalo $\mathrm{Mb}$ extracted from skeletal muscles [5]. The molecular mass of goat $\mathrm{Mb}$ observed in the present study is 75 Daltons higher than the report of Suman et al. (2009) [7]. In general it is agreed that the mass of $\mathrm{Mb}$ for all the livestock and poultry species is around 17000 Daltons.

Purified Mb protein separated by $2 \mathrm{DE}$ gel was identified by MALDI-TOF MS. The analysis of generated peptides along with their $m / z$ values and intensities revealed an abundant peptide with a $\mathrm{m} / \mathrm{z}$ value of 748 for buffalo $\mathrm{Mb}$ compared to goat $\mathrm{Mb}$ in which a peptide with $m / z$ of 1592 was most abundant (data not shown). The PMF results with details of molecular weight search score, number of matched peptides, nominal and observed mass along with \% sequence coverage has been given in Table 1. Clear distinction can be made from the result where there is a reducing ion score for goat samples relative to buffalo samples. Peptide masses detected in the present study were matched for buffalo and goat $\mathrm{Mb}$ proteins in a database which showed the sequence coverage of $39.61 \%$ for buffalo and $41.55 \%$ for goat. Four peptides matched for buffalo $\mathrm{Mb}$, whereas for goat $\mathrm{Mb}$ six peptides were matched. Furthermore, MALDI-TOF analysis consistently gave information on the peptidemass fingerprint from position 2-119 for buffalo and 2153 for goat samples. These results confirmed the identity of purified protein spot on 2DE gel as buffalo and 


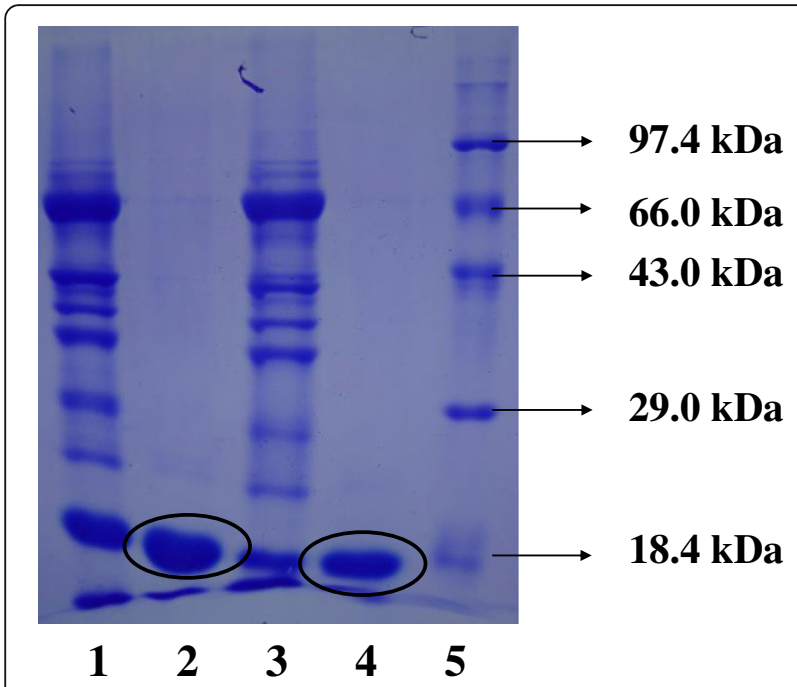

Fig. 2 SDS-PAGE pattern of samples obtained during purification of buffalo and goat cardiac myoglobins. Lane 1, buffalo sarcoplasmic protein extract; Lane 2, pure buffalo myoglobin; Lane 3, goat sarcoplasmic protein extract; lane 4, pure goat myoglobin; lane 5, molecular weight standard

goat Mb's. The observed differences in peptides and their masses between buffalo and goat samples is because of the fact that buffalo $\mathrm{Mb}$ has $95.4 \%$ sequence similarity with goat $\mathrm{Mb}$ (expacy.com).

\section{OFFGEL electrophoresis}

For the first time, we have attempted to use the OFFGEL electrophoresis to determine the isoelectric point $(\mathrm{p} I)$ of buffalo and goat Mb's. OFFGEL electrophoresis uses multi-compartment chamber on top of an IPG strip which provides the desired $\mathrm{pH}$ gradient and solubilized proteins migrate through the strip until they reach their $\mathrm{p} I$ at a given compartment and then return into solution [26]. Using the Agilent 3100 OFFGEL fractionator high resolution mode (24 fractions per $24 \mathrm{~cm}, 3-10$ IPG strip) with the Agilent's proprietary starter kit, buffalo and goat Mb's were fractionated separately. The $\mathrm{p} I$ was calculated by dividing the seven $\mathrm{pH}$ units of 3-10 gradient by the number of compartments, which is 24 in the present experiment. Each compartment corresponds to a $\mathrm{pH}$ resolution of 0.29 . After completion of OFFGEL electrophoresis, the fractionated samples from each well, in solution form were taken out and subjected to SDSPAGE. Out of 24 collected fractions each for buffalo and goat Mb's, single clear band corresponding to $17 \mathrm{kDa}$ molecular mass was obtained (figure not shown) at 14 and 16th fractions, respectively for buffalo and goat. Based on the fraction number corresponding to $17 \mathrm{kDa}$ band, the $\mathrm{p} I$ of buffalo and goat Mb's was calculated to be 6.77 and 7.35, respectively. Post-translational modification of proteins via phosphorylation leads to an acidic shift in the isoelectric $\mathrm{pH}$ which may result in variation [27]. The $\mathrm{p} I$ values investigated in the present study are almost similar to theoretical $\mathrm{p} I$ values of 6.71 and 7.38 for buffalo and goat Mb's respectively (web.expasy.org).

\section{HNE induced oxidation of buffalo and goat Oxy-Mb's}

HNE is a well-documented secondary product of $\omega-6$ polyunsaturated fatty acids oxidation. Various researchers have utilized HNE as a model oxidation product to study its interaction with Oxy-Mb from different livestock and poultry species as mentioned earlier [28]. To understand

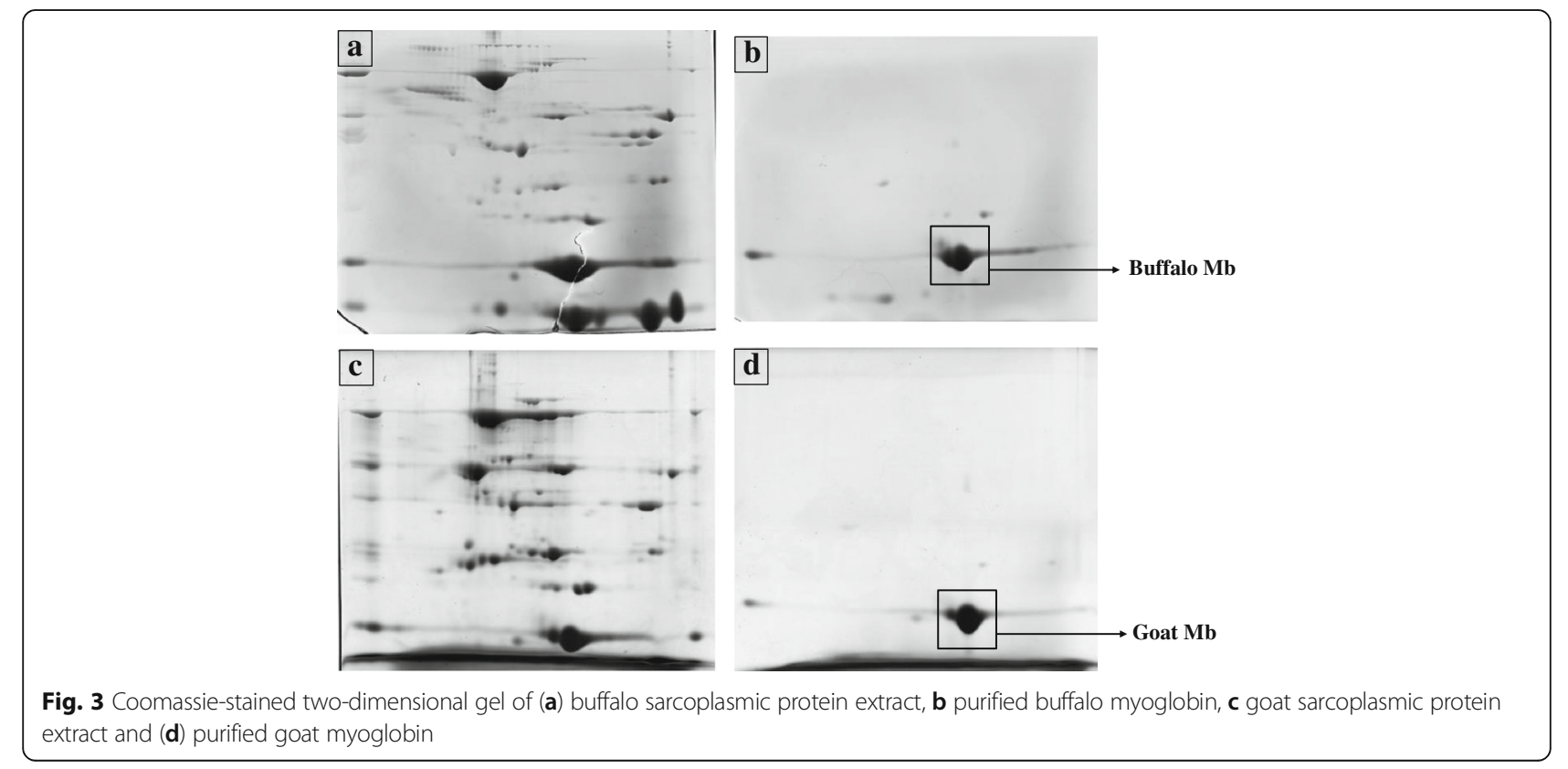




\section{Buffalo MB}

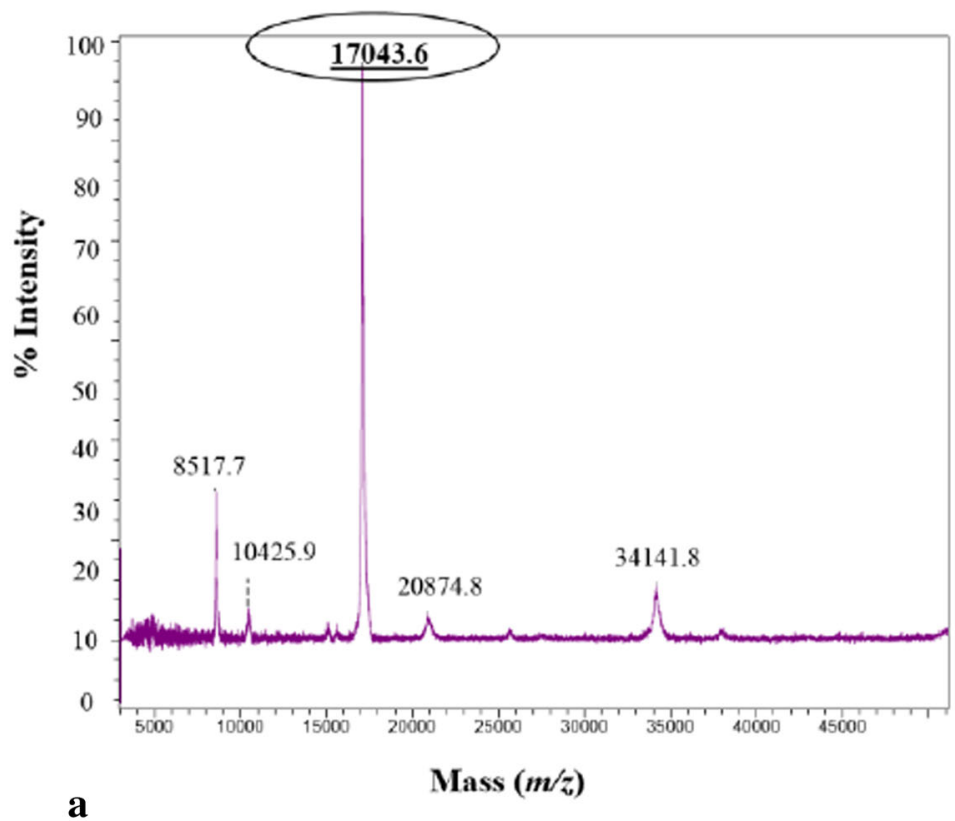

Goat MB

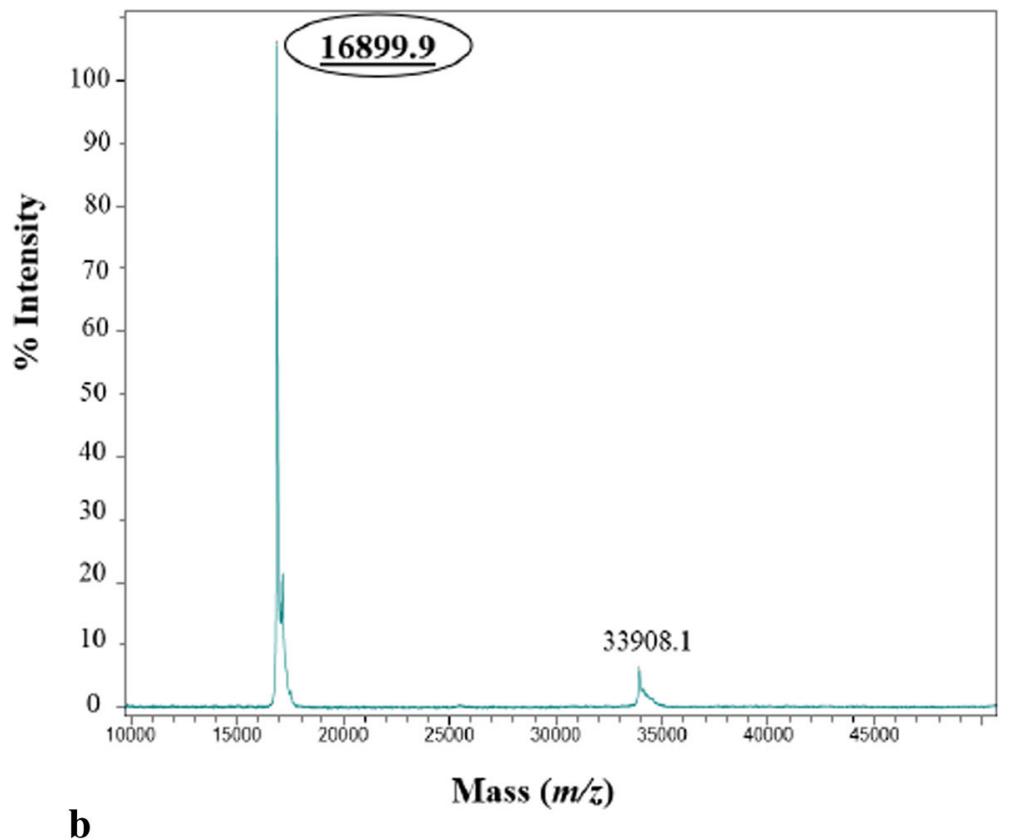

Fig. 4 MALDI-TOF mass spectra of purified (a) buffalo and $\mathbf{b}$ goat myoglobins

the proxidative effect of $\alpha, \beta$-unsaturated aldehyde, HNE was incubated with buffalo and goat Oxy-Mb's for $3.5 \mathrm{~h}$ at $25^{\circ} \mathrm{C}, \mathrm{pH} 5.6$ and $37^{\circ} \mathrm{C}, \mathrm{pH} 7.4$ to represent the $\mathrm{pH}$ values of post-mortem muscle and physiological conditions, respectively. Pure Mb without HNE (control) was also incubated along with $\mathrm{HNE}$ reacted $\mathrm{Mb}$ (treatment) for comparison under similar conditions. The \%Met-Mb formed during incubation of buffalo and goat Oxy-Mb's with
HNE (treatment) and without HNE (control) at $25{ }^{\circ} \mathrm{C}$, pH 5.6 and $37^{\circ} \mathrm{C}, \mathrm{pH} 7.4$ are presented in Figs. 5 and 6, respectively. When HNE was reacted with Oxy-Mb solutions, the \%Met-Mb formation was greater $(p<0.05)$ than controls at all the temperatures and $\mathrm{pH}$ conditions for both buffalo and goat. As expected, the \%Met-Mb formation is higher $(p<0.05)$ at $37{ }^{\circ} \mathrm{C}$ compared to $25{ }^{\circ} \mathrm{C}$. Oxy-Mb oxidation of both buffalo and goats were higher 
Table 1 Results of peptide mass fingerprinting (PMF) for identification of water buffalo (Bubalus bubalis) and goat meat (Capra hircus) myoglobins

\begin{tabular}{|c|c|c|c|c|c|c|}
\hline Species & $\begin{array}{l}\text { Accession } \\
\text { No. }\end{array}$ & Score & $\begin{array}{l}\text { No. matched } \\
\text { peptides }\end{array}$ & $\begin{array}{l}\text { Nominal } \\
\text { mass }\end{array}$ & $\begin{array}{l}\text { Observed } \\
\text { mass }\end{array}$ & \% Sequence coverage highlighting the matched peptides \\
\hline Buffalo (Bubalusbubalis) & gil116248552 & 289 & 4 & 17155.0 & 17043.6 & $\begin{array}{l}\text { Sequence coverage }=39.61 \% \\
\text { MGLSDGEWQLVLNAWGKVETDVAGHGQEVL IRLFTGHPET } \\
\text { LEKFDKFKHL KTEAEMKASE DLKKHGNTVLTALGGILKKK } \\
\text { GHHEAEVKHL AESHANKHKI PVKYLEFISDAIIHVLHDKH } \\
\text { PSDFGADAQA AMSKALELFR NEMAAQYKVL GFHG }\end{array}$ \\
\hline Goat (Capra hircus) & gil118595750 & 79 & 6 & 17043.0 & 16899.9 & $\begin{array}{l}\text { Sequence coverage }=41.55 \% \\
\text { MGLSDGEWTLVLNAWGKVEADVAGHGQEVLIRLFTGHPET } \\
\text { LEKFDKFKHL KTGAEMKASE DLKKHGNTVLTALGGILKKK } \\
\text { GHHEAEVKHL AESHANKHKI PVKYLEFISD AIIHVLHAKH } \\
\text { PSDFGADAQG AMSKALELFRNDMAAQYKVL GFQG }\end{array}$ \\
\hline
\end{tabular}

$(p<0.05)$ at $\mathrm{pH} 5.6$ relative to $\mathrm{pH} 7.4$, a result attributed to greater autoxidation. Similar results were observed during the incubation of HNE with equine, bovine and porcine Oxy-Mb's [9, 10, 12]. In general, the oxidising effect of HNE is greater at 7.4 compared to 5.6 potentially because of decreased nucleophilicity of candidate histidine residues at this $\mathrm{pH}$ [29]. Oxymyoglobin-HNE adduct formation was greater at $\mathrm{pH} 7.4$ than at $\mathrm{pH} 5.6$, because at acidic $\mathrm{pH}$ several ionizable imidazole groups (in HIS) are protonated and therefore, less reactive with HNE. The pKa value for the imidazole group of histidine is approximately 6.0, and therefore HIS residues would act as suitable nucleophilic targets for aldehyde adduction at $\mathrm{pH}$ 7.4. However, protonation of the imidazole ring at $\mathrm{pH} 5.6$ would render HIS residues a less favorable candidate for aldehyde adduction via Michael addition. This will contribute to the greater number of $\mathrm{HNE}$ adduction at $\mathrm{pH} 7.4$ than at typical meat $\mathrm{pH}$ (5.6) [12]. Further, Oxy-Mb oxidation at pH 5.6 will progress significantly rapid enough to mask any observable redox destabilizing effect of HNE. Considering these reasons and the earlier studies we used $\mathrm{pH} 7.4$ condition for further characterization of Mb-HNE adduction.
MALDI-TOF MS analysis of Mb-HNE reaction mix (intact protein) at the end of incubation period (after $3.5 \mathrm{~h})$ at $\mathrm{pH} 7.4$ and $37{ }^{\circ} \mathrm{C}$ revealed covalent binding of upto three and five molecules of HNE to buffalo (Fig. 7a) and goat (Fig. 7b) Oxy-Mb's, respectively. These results indicate that HNE adducts were formed via Michael addition as the adduct peaks corresponded to the mass of myoglobin plus $156 \mathrm{Da}$, the molecular mass of HNE. These results suggest that buffalo myoglobin was less susceptible to nucleophilic attack and subsequent adduction with HNE, compared to goat Mb. This explains the reason for higher \%Met-Mb formation observed for goat $\mathrm{Oxy}-\mathrm{Mb}$ than buffalo $\mathrm{Oxy}-\mathrm{Mb}$ when incubated with HNE. Research to date has demonstrated that a multitude of factors (endogenous and exogenous) contribute to meat color stability and biochemistry. Among several factors, adduction of lipid derived aldehydes with Oxy-Mb was reported to cause increased \%Met-Mb formation and redox instability in different livestock and poultry species [8]. Michael adduction of HNE with apomyoglobin (model heme protein lacking cysteine residue) was confirmed by Bolgar and Gaskell (1996) using ESI-MS and indicated

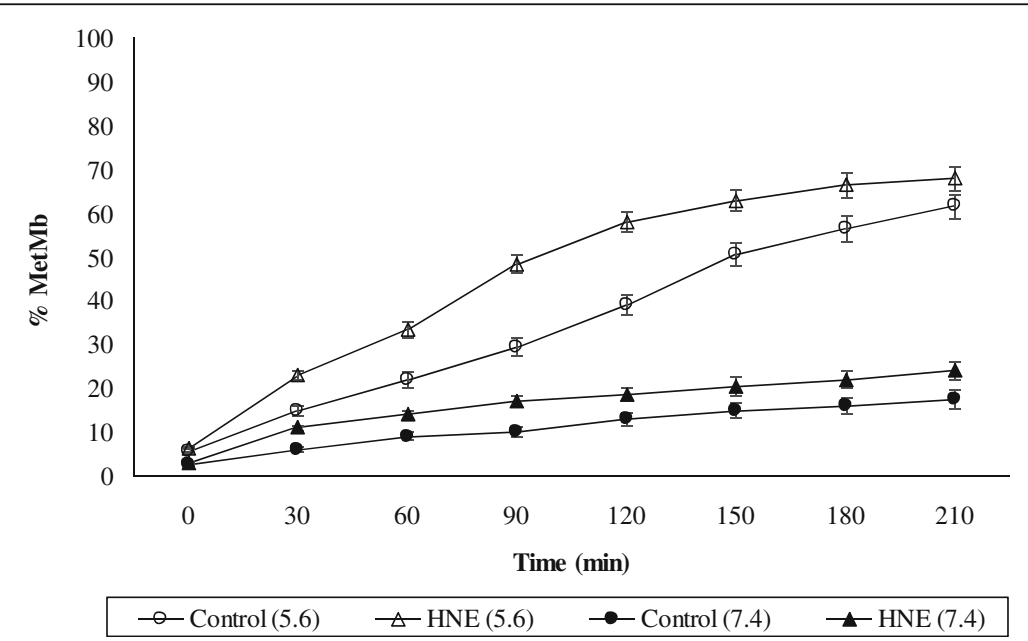

Fig. 5 Oxidation of buffalo meat oxymyoglobin reacted with HNE (treatment) and without HNE (control) at $25^{\circ} \mathrm{C}, \mathrm{pH} 5.6$ and $37^{\circ} \mathrm{C}$, pH 7.4 . Standard error bars are indicated $(n=3)$ 


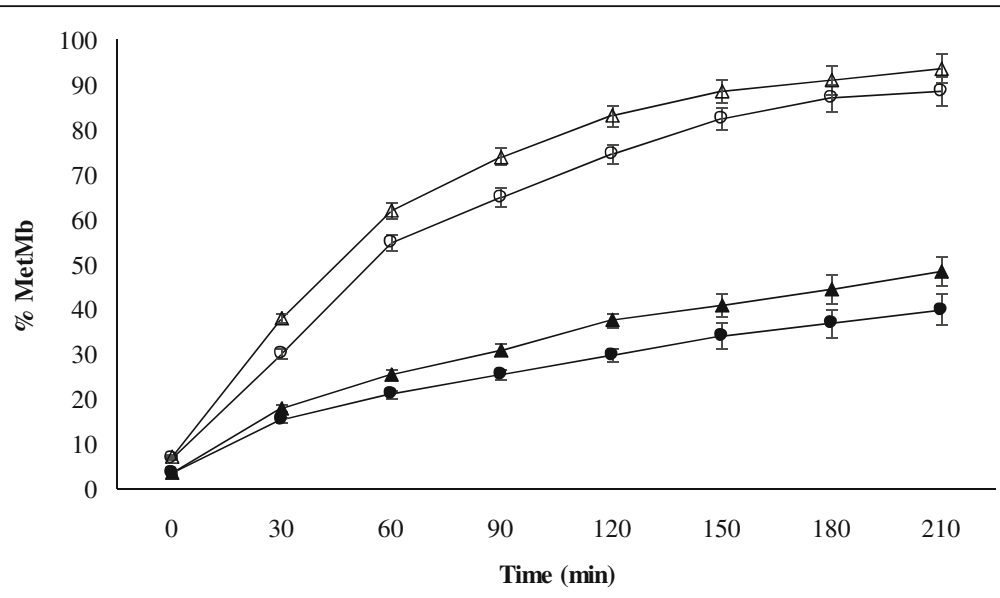

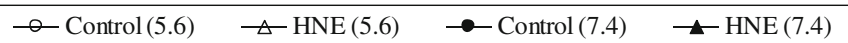

Fig. 6 Oxidation of goat meat oxymyoglobin reacted with HNE (treatment) and without HNE (control) at $25^{\circ} \mathrm{C}, \mathrm{pH} 5.6$ and $37^{\circ} \mathrm{C}, \mathrm{pH} 7.4$. Standard error bars are indicated $(n=3)$
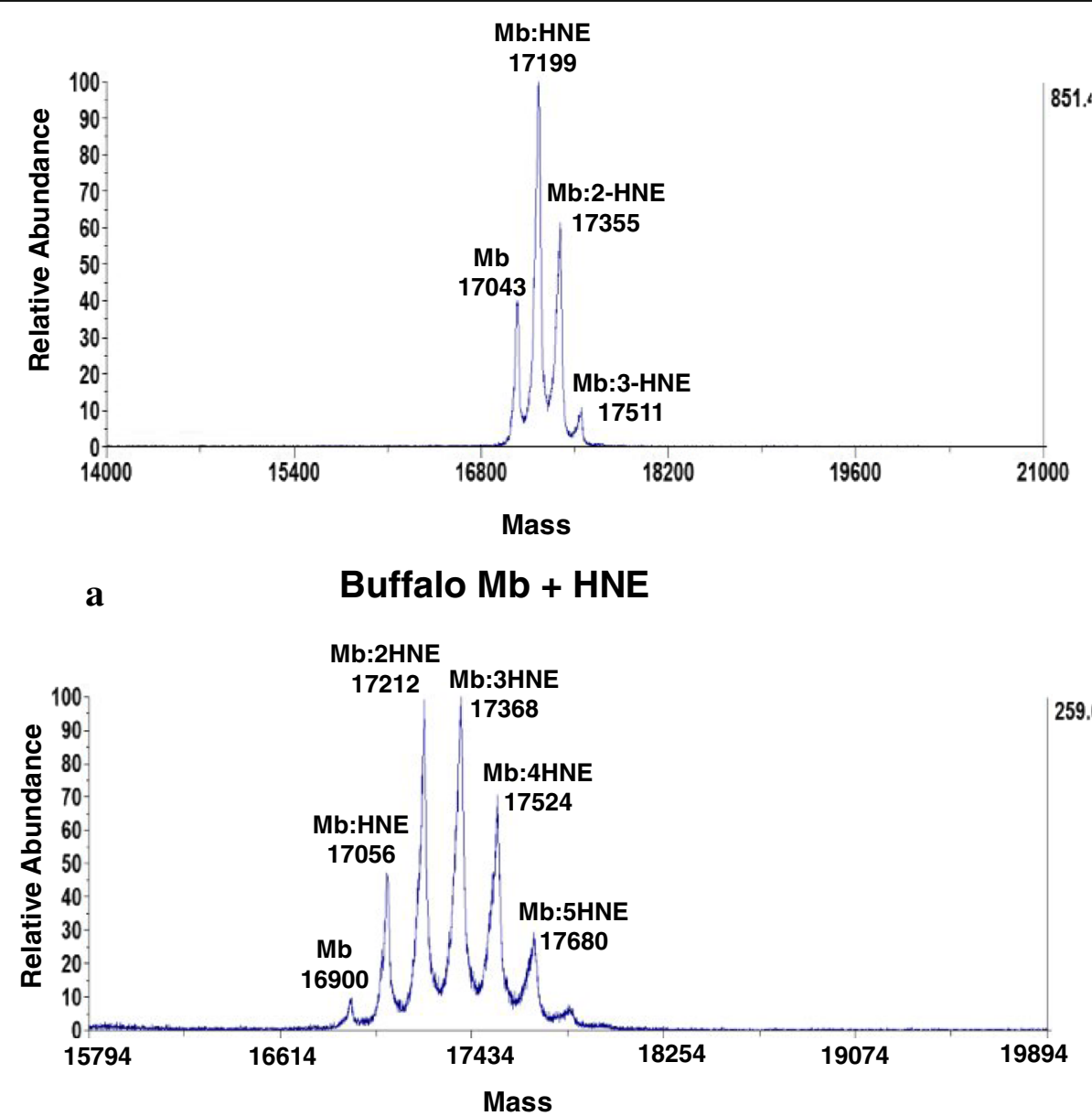

b

Goat Mb + HNE

Fig. 7 MALDI-TOF MS spectrum of (a) buffalo meat oxymyoglobin $(0.15 \mathrm{mM})$ reacted with HNE $(1.0 \mathrm{mM})$ and $\mathbf{b}$ goat meat oxymyoglobin $(0.075 \mathrm{mM})$ reacted with $\mathrm{HNE}(0.5 \mathrm{mM})$ at $\mathrm{pH} 7.4$ and $37^{\circ} \mathrm{C}$ for $3.5 \mathrm{~h}$ 
three to $10 \mathrm{HNE}$ adducts per protein molecule [30]. Faustman et al. (1999) and Alderton et al. (2003) have reported tri-adducts of HNE with equine and beef Oxy-Mb's incubated at $\mathrm{pH} 7.4$ and $37^{\circ} \mathrm{C}$ after 3 hours of incubation $[9,10]$. Species specific effect of Mb-HNE adducts were observed by previous researchers as indicated by monoadducts in porcine $\mathrm{Mb}$ at $\mathrm{pH} 5.6$ [12], di-adducts for chicken and turkey at $\mathrm{pH} 7.4$ [16], mono-adducts for emu and ostrich at $\mathrm{pH}$ 7.4 [17] during incubation for different time periods. Our present findings synergistically add to the existing knowledge that lipid oxidation induced oxidation of myoglobin from red meat species (equine meat, beef and sheep meat) is more pronounced relative to white meats (poultry species).

Adduction of Oxy-Mb with 4-hydroxy-2-nonenal would be expected to alter the protein's tertiary structure and predispose it to greater oxidation [14]. The specific sites of HNE adduction in buffalo and goat Mb's incubated with and without (control) HNE were further investigated using ESI-QTOF MS/MS specifically at histidine (HIS) site as the earlier researchers have confirmed that HIS was the sole amino acid adducted by HNE $[10,12]$. The spectra corresponding to unadducted and adducted $\mathrm{Mb}$ peptides were identified and the $b$ - and $y$-series ions for seven buffalo $\mathrm{Mb}$ peptides with HNE adductions are summarized in Table 2. In the present study, we identified seven nucleophilic histidine residues for buffalo $\mathrm{Mb}$ confirmed to be adducted with HNE. The HIS 24, 36, 81, 88, 93, 119 and 152 each had a mass addition of 158 Da which is 2-Da higher than the mass of HNE. Previous study by Alderton et al. (2003) revealed a mass increment of $156 \mathrm{Da}$ due to HNE adduction via Michael addition [10]. The difference of 2-Da (156 vs. 158) in the present study could be due to protonation of HNE-adducted HIS which might have resulted in a 2-Da addition to the adduct's molecular mass and it is in agreement with Suman et al. (2007) [12]. For goat $\mathrm{Mb}$ we identified nine nucleophilic histidine residues confirmed to be adducted with HNE. The HIS 24, 36, 64, 81, 88, 97, 113, 116 and 119 each had a mass addition of $158 \mathrm{Da}$. The spectra corresponding to unadducted and adducted $\mathrm{Mb}$ peptides were identified and the $b$ - and $y$ series ions for goat $\mathrm{Mb}$ peptides with HNE adductions are summarized in Table 3. Compared to buffalo $\mathrm{Mb}$, goat $\mathrm{Mb}$ had two additional HNE adductions. Our results for buffalo Mb-HNE adductions were similar to the findings of Suman et al. (2007) who has also observed seven beef $\mathrm{Mb}-\mathrm{HNE}$ adductions under similar $\mathrm{pH}$ and temperature conditions [12]. This is because of the fact that both buffalo and cattle shares $98 \%$ sequence similarity with 13 total histidine residues in each located at the same position. Similar to the findings of Suman et al. (2007), HIS 88 and HIS 93 originating from the same peptide (HLAESHANK, position 88-96) were found adducted to HNE [12]. Simultaneous adduction at histidine 88 and histidine 93 was not detected because of the fact that alkylation of one histidine prevents the other nearby histidine residue from being alkylated due to steric hindrance [19].

An interesting finding in our study is that, goat $\mathrm{Mb}$ with 95.4\% and $97.4 \%$ sequence identity with buffalo and beef $\mathrm{Mb}$, respectively with 12 total histidine residues exhibited 9 $\mathrm{HNE}$ adductions. Similar to buffalo Mb, even for goat $\mathrm{Mb}$ HIS 113 and HIS 116 originating from same peptide (YLEFISDAIIHVLHAK, position 103-118) were found adducted to HNE. The difference in HNE adductions between buffalo and goat Mb's is presented in Table 4. These results indicate a difference in HNE adduction between buffalo and goat Mb's both in terms of number and location of adductions. We observed the adduction of proximal HIS 93 in buffalo, whereas for goat the adduction of distal HIS 64 was found. This is of great significance as HIS 93, the proximal histidine, is bound to the heme moiety of $\mathrm{Mb}$, whereas distal HIS 64, coordinates with oxygen or other molecules associated with the sixth ligand during the interconversion of $\mathrm{Mb}$ redox forms (i.e., Oxy-Mb and Met-Mb). Because HIS 93 and 64 lie in close proximity to the heme group, their modification by HNE could be expected to alter the protein structure around the heme cleft and subsequently impact redox stability. In their study comparing HNE induced oxidation of beef and pork Oxy-Mb's Suman et al. (2007) observed that fewer HIS residues were adducted by HNE in porcine $\mathrm{Mb}$ when compared to bovine $\mathrm{Mb}$, which suggested an apparently lower susceptibility of porcine $\mathrm{Mb}$ to the redox destabilizing effect of HNE [12]. They concluded that preferential HNE adduction at proximal residue (HIS 93), exclusively observed in bovine Oxy-Mb might result in more pronounced $\mathrm{Oxy}-\mathrm{Mb}$ oxidation in beef relative to pork. Our findings indicate that goat Oxy-Mb with $\mathrm{HNE}$ adduction at distal histidine (HIS 64) results in more pronounced Oxy-Mb oxidation resulting in higher \% Met-Mb than beef $\mathrm{Mb}$ with $\mathrm{HNE}$ adduction at proximal histidine (HIS 93). Yin et al. (2011) studied the HNE induced oxidation of Oxy-Mb's from seven different meat animals and concluded that, the relative effect of HNE was greater for Mb's that contained $12 \pm 1$ histidine residues than for those that contained nine histidine residues [31]. Table 4 clearly indicate greater number of adductions and alkylation of more HIS residues in red meat producing livestocks (12 or 13 HIS) except pork (nine histidine) relative to poultry birds (eight or nine histidine). Present study confirm these findings, wherein livestock Mb's with higher number of histidine residues results in greater Mb-HNE adducts and more covalently modified histidine residues leading to increased susceptibility for lipid oxidation induced oxidation.

\section{Conclusions}

In conclusion, results obtained from this study revealed that buffalo and goat Mb's were similar in behaviour during isolation and purification and exhibited a molecular mass of 
Table 2 MS/MS spectral features of unadducted and HNE-adducted water buffalo (Bubalus bubalis) myoglobin peptides

\begin{tabular}{|c|c|c|c|c|}
\hline Peptide position ${ }^{a}$ & Peptide sequence ${ }^{\text {b) }}$ & Modification and mass shift & Precursor $\mathrm{m} / \mathrm{z}$ & b and y ions identified ${ }^{c)}$ \\
\hline $17-31$ & VETDVAGHGQEVLIR & Unadducted & 1604.83 & 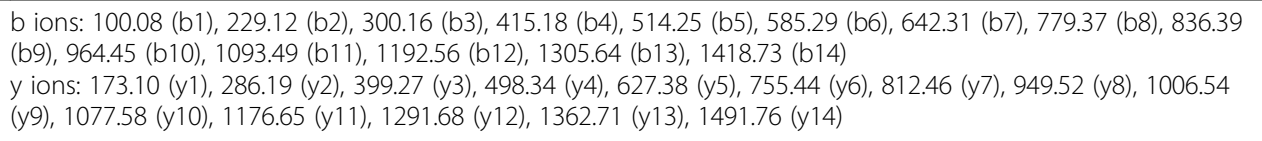 \\
\hline $17-31$ & VETDVAGHGQEVLIR & $\mathrm{HNE}+158.1$ & 1604.84 & 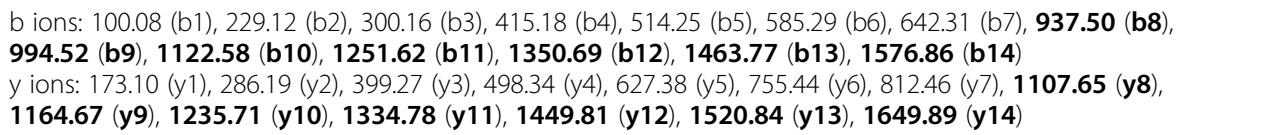 \\
\hline $32-42$ & LFTGHPETLEK & Unadducted & 1271.66 & $\begin{array}{l}\text { b ions: } 114.09 \text { (b1), } 261.16 \text { (b2), } 362.21 \text { (b3), } 419.23 \text { (b4), } 556.29 \text { (b5), } 653.34 \text { (b6), } 782.38 \text { (b7), } 883.43 \text { (b8), } 996.52 \\
\text { (b9), } 1125.56 \text { (b10) } \\
\text { y ions: } 145.10 \text { (y1), } 274.14 \text { (y2), } 387.22 \text { (y3), } 488.27 \text { (y4), } 617.31 \text { (y5), } 714.37 \text { (y6), } 851.43 \text { (y7), } 908.45 \text { (y8), } 1009.50 \\
\text { (y9), } 1156.56 \text { (y10) }\end{array}$ \\
\hline $32-42$ & LFTGHPETLEK & $\mathrm{HNE}+158.1$ & 1253.65 & 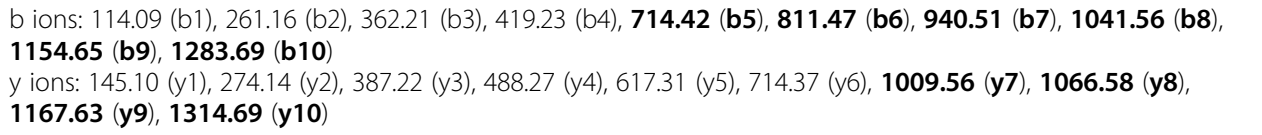 \\
\hline 80-87 & GHHEAEVK & Unadducted & 1893.90 & $\begin{array}{l}\text { b ions: } 58.03(\mathrm{~b} 1), 195.09(\mathrm{~b} 2), 332.15(\mathrm{~b} 3), 461.19(\mathrm{~b} 4), 532.23(\mathrm{~b} 5), 661.27(\mathrm{~b} 6), 760.34(\mathrm{~b} 7) \\
\text { y ions: } 145.10(\mathrm{y} 1), 244.17(\mathrm{y} 2), 373.21(\mathrm{y} 3), 444.25(\mathrm{y} 4), 573.29(\mathrm{y} 5), 710.35(\mathrm{y} 6), 847.41(\mathrm{y} 7)\end{array}$ \\
\hline 80-87 & GHHEAEVK & $\mathrm{HNE}+158.1$ & 1893.93 & 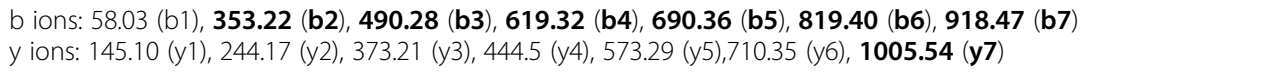 \\
\hline 88-96 & HLAESHANK & Unadducted & 1253.65 & $\begin{array}{l}\text { b ions: } 138.07 \text { (b1), } 251.15 \text { (b2), } 322.19(\mathrm{~b} 3), 451.23(\mathrm{~b} 4), 538.26(\mathrm{~b} 5), 675.32(\mathrm{~b} 6), 746.36(\mathrm{~b} 7), 860.40(\mathrm{~b} 8) \\
\mathrm{y} \text { ions: } 145.10(\mathrm{y} 1), 259.14(\mathrm{y} 2), 330.18(\mathrm{y} 3), 467.24(\mathrm{y} 4), 554.27(\mathrm{y} 5), 683.70(\mathrm{y} 6), 754.78(\mathrm{y} 7), 867.94(\mathrm{y} 8)\end{array}$ \\
\hline $88-96$ & HLAESHANK & $\mathrm{HNE}+158.1$ & 1253.65 & $\begin{array}{l}\text { b ions: } \mathbf{2 9 6 . 2 0}(\mathbf{b} 1), \mathbf{4 0 9 . 2 8}(\mathbf{b 2}), \mathbf{4 8 0 . 3 2}(\mathbf{b 3}), \mathbf{6 0 9 . 7 4}(\mathbf{b} 4), \mathbf{6 9 6 . 8 2}(\mathbf{b} 5), \mathbf{8 3 3 . 9 6}(\mathbf{b 6}), \mathbf{9 0 5 . 0 4}(\mathbf{b 7}), \mathbf{1 0 1 9 . 1 5} \text { (b8) } \\
y \text { ions: } 145.10(\mathrm{y} 1), 259.14(\mathrm{y} 2), 330.18(\mathrm{y} 3), 467.24(\mathrm{y} 4), 554.27(\mathrm{y} 5), 683.70(\mathrm{y} 6), 754.78(\mathrm{y} 7), 867.94(\mathrm{y} 8)\end{array}$ \\
\hline 88-96 & HLAESHANK & Unadducted & 1271.66 & $\begin{array}{l}\text { b ions: } 138.07 \text { (b1), } 251.15(\mathrm{~b} 2), 322.19(\mathrm{~b} 3), 451.23(\mathrm{~b} 4), 538.26(\mathrm{~b} 5), 675.32(\mathrm{~b} 6), 746.36(\mathrm{~b} 7), 860.40(\mathrm{~b} 8) \\
\mathrm{y} \text { ions: } 145.10(\mathrm{y} 1), 259.14(\mathrm{y} 2), 330.18(\mathrm{y} 3), 467.24(\mathrm{y} 4), 554.27(\mathrm{y} 5), 683.70(\mathrm{y} 6), 754.78(\mathrm{y} 7), 867.94(\mathrm{y} 8)\end{array}$ \\
\hline 88-96 & HLAESHANK & $\mathrm{HNE}+158.1$ & 1271.66 & $\begin{array}{l}\text { b ions: } 138.07 \text { (b1), } 251.15 \text { (b2), } 322.19 \text { (b3), } 451.23 \text { (b4), } 538.26 \text { (b5), } 833.96 \text { (b6), } 905.04(\mathbf{b 7}), \mathbf{1 0 1 9 . 1 5}(\mathbf{b 8}) \\
\text { y ions: } 145.10(\mathrm{y} 1), 259.14(\mathrm{y} 2), 330.18(\mathrm{y} 3), \mathbf{6 2 5 . 7 5} \text { (y4), } 712.82 \text { (y5), } 841.94(\mathbf{y 6}), \mathbf{9 1 3 . 0 2}(\mathbf{y 7}), \mathbf{1 0 2 6 . 1 8}(\mathbf{y 8})\end{array}$ \\
\hline 119-133 & HPSDFGADAQAAMSK & Unadducted & 1514.67 & $\begin{array}{l}\text { b ions: } 138.07 \text { (b1), } 235.12 \text { (b2), } 322.15 \text { (b3), } 437.18 \text { (b4), } 584.25 \text { (b5), } 641.27 \text { (b6), } 712.31 \text { (b7), } 827.33 \text { (b8), } 898.37 \\
\text { (b9), 1026.43 (b10), } 1097.47 \text { (b11), } 1168.50 \text { (b12) } \\
\text { y ions: } 363.17 \text { (y1), } 434.21 \text { (y2), } 505.24(y 3), 633.30 \text { (y4), } 704.34 \text { (y5), } 819.37 \text { (y6), } 890.40 \text { (y7), } 947.43(y 8), 1094.49 \\
\text { (y9), } 1209.52 \text { (y10), 1296.55 (y11), } 1393.61 \text { (y12) }\end{array}$ \\
\hline 119-133 & HPSDFGADAQAAMSK & $\mathrm{HNE}+158.1$ & 1532.68 & 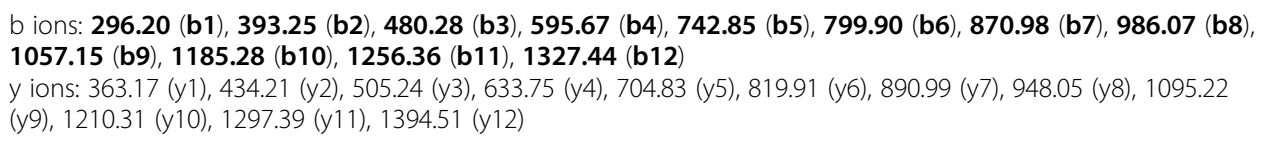 \\
\hline 148-153 & VLGFHG & Unadducted & 629.34 & $\begin{array}{l}\text { b ions: } 100.08(\mathrm{~b} 1), 213.16(\mathrm{~b} 2), 270.18(\mathrm{~b} 3), 417.25(\mathrm{~b} 4), 554.31(\mathrm{~b} 5) \\
\text { y ions: } 74.02(\mathrm{y} 1), 211.08(\mathrm{y} 2), 358.15(\mathrm{y} 3), 415.17(\mathrm{y} 4), 528.26(\mathrm{y} 5)\end{array}$ \\
\hline 148-153 & VLGFHG & $\mathrm{HNE}+158.1$ & 629.34 & $\begin{array}{l}\text { b ions: } 100.08(\mathrm{~b} 1), 213.16(\mathrm{~b} 2), 270.18(\mathrm{~b} 3), 417.25(\mathrm{~b} 4), \mathbf{7 1 2 . 9 1}(\mathbf{b} 5) \\
\text { y ions: } 74.02(\mathrm{y} 1), \mathbf{3 6 9 . 2 1}(\mathbf{y 2}), \mathbf{5 1 6 . 2 8}(\mathbf{y 3}), \mathbf{5 7 3 . 3 0}(\mathbf{y 4}), \mathbf{6 8 6 . 8 3}(\mathbf{y 5})\end{array}$ \\
\hline
\end{tabular}

a) Amino acid position in the water buffalo $\mathrm{Mb}$; b) Amino acid sequence in the water buffalo Mb; c) Observed signals assigned as $b$ or $y$ ions. lons showing shift in the mass by 156 Da indicating HNE adduction with respect to corresponding ions in unmodified peptides are highlighted in bold fonts 
Table 3 MS/MS spectral features of unadducted and HNE-adducted goat (Capra hircus) meat myoglobin peptides

\begin{tabular}{|c|c|c|c|c|}
\hline $\begin{array}{l}\text { Peptide positiona) } \\
\text { a) }\end{array}$ & Peptide sequence ${ }^{b)}$ & Modification and mass shift & Precursor $\mathrm{m} / \mathrm{z}$ & $\mathrm{b}$ and $\mathrm{y}$ ions identified ${ }^{\mathrm{c})}$ \\
\hline $17-31$ & VEADVAGHGQEVLIR & Unadducted & 1592.77 & 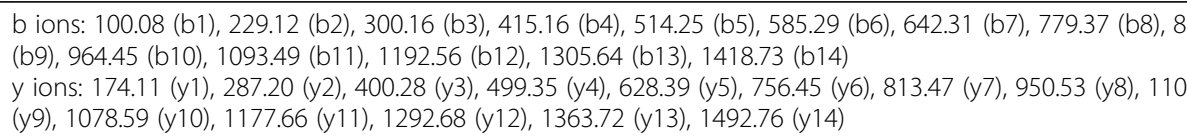 \\
\hline $17-31$ & VEADVAGHGQEVLIR & $\mathrm{HNE}+158.1$ & 1751.01 & 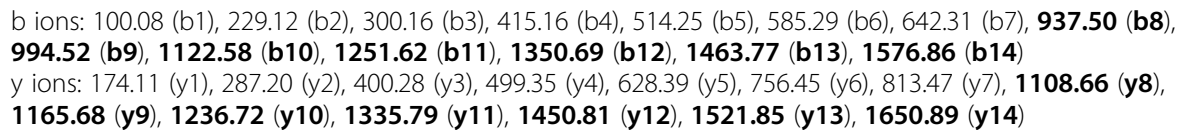 \\
\hline
\end{tabular}

32-42 LFTGHPETLEK Unadducted

32-42 LFTGHPETLEK HNE + 158.1
1271.43

b ions: 114.09 (b1), 261.16 (b2), 362.21 (b3), 419.23 (b4), 556.29 (b5), 653.34 (b6), 782.38 (b7), 883.43 (b8), 996.52 (b9), 1125.56 (b10) y ions: 146.11 (y1), 275.15 (y2), 388.23 (у3), 489.28 (y4), 618.32 (y5), 715.38 (y6), 852.43 (y7), 909.46 (y8), 1010.50 (y9), 1157.57 (y10)

1429.67 b ions: 114.09 (b1), 261.16 (b2), 362.21 (b3), 419.23 (b4), 714.42 (b5), 811.47 (b6), 940.51 (b7), 1041.56 (b8), 1154.65 (b9), 1283.69 (b10) y ions: 146.11 (y1), 275.15 (y2), 388.23 (y3), 489.28 (y4), 618.32 (y5), 715.38 (y6), 1010.56 (y7), 1067.59 (y8), $1168.63(\mathrm{y} 9), 1315.70(\mathbf{y} 10)$

1521.82 b ions: 129.10 (b1), 266.16 (b2), 323.18 (b3), 437.23 (b4), 538.27 (b5), 637.34 (b6), 750.43 (b7), 851.47 (b8), 922.5 (b9), 1035.60 (b10), 1092.62 (b11), 1149.64 (b12), 1262.72 (b13), 1375.81 (b14) y ions: $146.11(y 1), 259.19$ (y2), 372.27 (y3), 429.30 (y4), 486.32 (y5), 599.40 (y6), 670.44 (y7), 771.49 (y8), 884.57 (y9), 983.64 (y10), 1084.69 (y11), 1198.73 (y12), 1255.75 (y13), 1392.81 (y14)

1680.06 b ions: 129.10 (b1), 424.29 (b2), 481.31 (b3), 595.36 (b4), 696.40 (b5), 795.47 (b6), 908.56 (b7), 1009.60 (b8) 1080.64 (b9), 1193.73 (b10), 1250.75 (b11), 1307.77 (b12), 1420.85 (b13), 1533.94 (b14 y ions: 146.11 (y1), 259.11 (y2), 372.27 (y3), 429.30 (y4), 486.32 (y5), 599.40 (y6), 670.44 (y7), 771.49 (y8), 884.57 (y9), 983.64 (y10), 1084.69 (y11), 1198.73 (y12), 1255.75 (y13), 1550.94 (у14)

905.96 b ions: 58.03 (b1), 195.09 (b2), 332.15 (b3), 461.19 (b4), 532.23 (b5), 661.27 (b6), 760.34 (b7) y ions: 146.11 (y1), $245.17(\mathrm{y} 2), 374.22(\mathrm{y} 3), 445.25$ (y4), 574.30 (y5), 711.36 (y6), 848.41 (y7)

1064.20 b ions: 58.03 (b1), 353.22 (b2), 490.28 (b3), 619.32 (b4), 690.36 (b5), 819.40 (b6), 918.47 (b7) y ions: $146.11(\mathrm{y} 1), 245.17(\mathrm{y} 2), 374.22(\mathrm{y} 3), 445.25$ (y4), $574.30(\mathrm{y} 5), 711.36(\mathrm{y} 6), \mathbf{1 0 0 6 . 5 4}(\mathbf{y} 7)$

1271.40 b ions: 138.07 (b1), 251.15 (b2), 322.19 (b3), 451.23 (b4), 538.26 (b5), 675.32 (b6), 746.36 (b7), 860.40 (b8), 988.50 (b9), 1125.56 (b10) y ions: 146.11 (y1), 283.16 (y2), 411.26 (у3), 525.30 (у4), 596.34 (y5), 733.40 (y6), 820.43 (y7), 949.47 (y8), 1020.51 (y9), 1133.59 (y10)

1164.32 b ions: 296.20 (b1), 409.28 (b2), 480.38 (b3), 609.36 (b4), 696.39 (b5), 833.45 (b6), 904.49 (b7), 1018.53 (b8) $\mathrm{y}$ ions: $146.11(\mathrm{y} 1), 260.15(\mathrm{y} 2), 331.19(\mathrm{y} 3), 468.24(\mathrm{y} 4), 555.28(\mathrm{y} 5), 684.32(\mathrm{y} 6), 755.36(\mathrm{y} 7), 868.44(\mathrm{y} 8)$

1271.40 b ions: 138.07 (b1), 251.15 (b2), 322.19 (b3), 451.23 (b4), 538.26 (b5), 675.32 (b6), 746.36 (b7), 860.40 (b8), 988.50 (b9), 1125.56 (b10) y ions: 146.11 (y1), 283.16 (y2), 411.26 (y3), 525.30 (y4), 596.34 (y5), 733.40 (y6), 820.43 (y7), 949.47 (y8), 1020.51 (y9), 1133.59 (y10)

1429.64 b ions:138.07 (b1), 251.15 (b2), 322.19 (b3), 451.23 (b4), 538.26 (b5), 675.32 (b6), 746.36 (b7), 860.40 (b8), 988.50 (b9), 1283.69 (b10

y ions: 146.11 (y1), 441.30 (y2), 569.39 (y3), 683.43 (y4), 754.47 (y5), 891.53 (y6), 978.56 (y7), 1107.60 (y8) $1178.64(\mathrm{y} 9), 1291.72(\mathrm{y} 10$ 
Table 3 MS/MS spectral features of unadducted and HNE-adducted goat (Capra hircus) meat myoglobin peptides (Continued)

103-118 YLEFISDAIIHVLHAK Unadducted

YLEFISDAIIHVLHAK HNE + 158.1

103-118

103-118

YLEFISDAIIHVLHAK Unadducted

103-118

YLEFISDAIIHVLHAK $\quad$ HNE +158.1

119-133

HPSDFGADAQGAMSK Unadducted

119-133

HPSDFGADAQGAMSK HNE + 158.1
1869.19

b ions: 164.07 (b1) 277.16 (b2), 406.20 (b3), 553.27 (b4), 666.35 (b5), 753.38 (b6), 868.41 (b7), 939.45 (b8), 1052.53 (b9), 1165.61 (b10), 1302.67 (b11), 1401.74 (b12), 1514.83 (b13), 1651.88 (b14), 1722.92 (b15)

y ions: $146.11(y 1), 217.14(y 2), 354.20$ (y3), 467.29 (y4), 566.35 (y5), 703.41 (y6), 816.50 (y7), 929.58 (y8), 1000.62 (y9), 1115.65 (y10), 1202.68 (y11), 1315.76 (y12), 1462.83 (y13), 1591.95 (y14), 1704.96 (y15)

2027.43 b ions: 164.07 (b1), 277.16 (b2), 406.20 (b3), 553.27 (b4), 666.35 (b5), 753.38 (b6), 868.41 (b7), 939.45 (b8), 1052.53 (b9), 1165.61 (b10), 1460.80 (b11), 1559.87 (b12), 1672.96 (b13), 1810.02 (b14), 1881.05 (b15)

y ions: $146.11(\mathrm{y} 1), 217.14(\mathrm{y} 2), 354.20(\mathrm{y} 3), 467.29(\mathrm{y} 4), 566.35$ (y5), $861.54(\mathbf{y 6}), \mathbf{9 7 4 . 6 3}(\mathbf{y 7}), \mathbf{1 0 8 7 . 7 1}(\mathbf{y 8})$ 1158.75 (y9), 1273.78 (y10), 1360.81 (y11), 1473.89 (y12), 1620.96 (y13), 1750.00 (y14), 1863.09 (y15)

1869.19 b ions: 164.07 (b1), 277.16 (b2), 406.20 (b3), 553.27 (b4), 666.35 (b5), 753.38 (b6), 868.41 (b7), 939.45 (b8), 1052.53 (b9), 1165.61 (b10), 1302.67 (b11), 1401.74 (b12), 1514.83 (b13), 1651.88 (b14), 1722.92 (b15)

y ions: $146.11(\mathrm{y} 1), 217.14(\mathrm{y} 2), 354.20(\mathrm{y} 3), 467.29(\mathrm{y} 4), 566.35$ (y5), 703.41 (y6), 816.50 (y7), 929.58 (y8), 1000.62 (y9), 1115.65 (y10), 1202.68 (y11), 1315.76 (y12), 1462.83 (y13), 1591.95 (y14), 1704.96 (y15)

2027.43 b ions: 164.07 (b1), 277.16 (b2), 406.20 (b3), 553.27 (b4), 666.35 (b5), 753.38 (b6), 868.41 (b7), 939.45 (b8), 1052.53 (b9), 1165.61 (b10), 1302.67 (b11), 1401.74 (b12), 1514.83 (b13), 1810.02 (b14), 1881.05 (b15)

$y$ ions: $146.11(y 1), 217.14(y 2), 512.33(y 3), 625.42(\mathbf{y 4}), 724.48(\mathbf{y 5}), 861.54(\mathbf{y 6}), 974.63(\mathbf{y} 7), 1087.71(\mathbf{y 8})$ 1158.75 (y9), 1273.78 (y10), 1360.81 (y11), 1473.89 (y12), 1620.96 (y13), 1750.00 (y14), 1863.09 (y15)

1518.62 b ions: 138.07 (b1), 235.12 (b2), 322.15 (b3), 437.18 (b4), 584.25 (b5), 641.27 (b6), 712.31 (b7), 827.33 (b8), 898.37 (b9), 1026.43 (b10), 1083.45 (b11), 1154.49 (b12), 1285.53 (b13), 1372.56 (b14)

y ions: $146.11(y 1), 233.14(y 2), 364.18(y 3), 435.22$ (y4), $492.4(y 5), 620.30(y 6), 691.33$ (y7), $806.36(y 8), 877.40$ (y9), 934.42 (y10), $1081.49(\mathrm{y} 11), 1196.51$ (y12), 1283.55 (y13), 1380.60 (y14)

1676.86 b ions: 296.20 (b1), 393.25 (b2), 480.28 (b3), 595.67 (b4), 742.85 (b5), 799.40 (b6), 870.44 (b7), 985.46 (b8), 1056.50 (b9), 1184.56 (b10), 1241.58 (b11), 1312.62 (b12), 1443.66 (b13), 1530.69 (b14)

y ions: $146.11(y 1), 233.14(y 2), 364.18(y 3), 435.22(y 4), 492.24$ (y5), 620.30 (y6), 691.33 (y7), $806.36(y 8), 877.40$ (y9), 934.42 (y10), 1081.49 (y11), 1196.51 (y12), 1283.55 (y13), 1380.60 (y14)

a) Amino acid position in the goat Mb; b) Amino acid sequence in the goat Mb; c) Observed signals assigned as $b$ or $y$ ions. lons showing shift in the mass by 156 Da indicating HNE adduction with respect to corresponding ions in unmodified peptides are highlighted in bold fonts 
Table 4 Comparison of Mb-HNE adductions and number of covalently modified histidine (HIS) residues in different meat animals and poultry

\begin{tabular}{|c|c|c|c|c|c|c|c|}
\hline $\begin{array}{l}\text { Meat animals } \\
\text { and poultry }\end{array}$ & $\begin{array}{l}\text { Total No. } \\
\text { HIS residues }\end{array}$ & $\begin{array}{l}\text { Mb-HNE incubation } \\
\text { conditions }\end{array}$ & $\begin{array}{l}\text { Incubation } \\
\text { time }\end{array}$ & $\begin{array}{l}\text { No. Mb-HNE } \\
\text { adductions }\end{array}$ & $\begin{array}{l}\text { Modified } \\
\text { HIS residues }\end{array}$ & $\begin{array}{l}\text { Position of adducted } \\
\text { HIS residues }\end{array}$ & Reference \\
\hline \multicolumn{8}{|l|}{ Meat animals } \\
\hline Water buffalo (bovine) & 13 & $\mathrm{pH} 7.4,37^{\circ} \mathrm{C}$ & $210 \mathrm{~min}$ & 3 & 7 & $24,36,81,88,93,119,152$ & Present study \\
\hline Goat (caprine) & 12 & $\mathrm{pH} 7.4,37^{\circ} \mathrm{C}$ & $210 \mathrm{~min}$ & 5 & 9 & $24,36,64,81,88,97,113,116,119$ & Present study \\
\hline Horse (equine) & 11 & $\mathrm{pH} 7.4,37^{\circ} \mathrm{C}$ & $160 \mathrm{~min}$ & 3 & ー-——— & -—-—-— & [9] \\
\hline \multirow[t]{2}{*}{ Cattle (bovine) } & 13 & $\mathrm{pH} 7.4,37^{\circ} \mathrm{C}$ & $160 \mathrm{~min}$ & 3 & 7 & $24,36,81,88,93,119,152$ & [12] \\
\hline & & & & 3 & 6 & $24,64,93,116,119,152$ & [10] \\
\hline Pig (porcine) & 9 & $\mathrm{pH} 7.4,37^{\circ} \mathrm{C}$ & $240 \min$ & 1 & 3 & $24,36,119$ & [12] \\
\hline Sheep (ovine) & 12 & $\mathrm{pH} 7.4,37^{\circ} \mathrm{C}$ & $240 \min$ & 3 & 3 & $25,65,120$ & [18] \\
\hline \multicolumn{8}{|l|}{ Poultry } \\
\hline Chicken & 9 & $\mathrm{pH} 5.8,25^{\circ} \mathrm{C}$ & $240 \min$ & 2 & 2 & 64,93 & [11] \\
\hline Turkey & 9 & $\mathrm{pH} 5.8,25^{\circ} \mathrm{C}$ & $240 \mathrm{~min}$ & 2 & -———- & -二-二-二 & [11] \\
\hline Ostrich & 8 & $\mathrm{pH} 7.4,37^{\circ} \mathrm{C}$ & $360 \mathrm{~min}$ & 1 & 1 & 36 & [17] \\
\hline Emu & 9 & $\mathrm{pH} 7.4,37^{\circ} \mathrm{C}$ & $360 \mathrm{~min}$ & 1 & 2 & 34,36 & [17] \\
\hline
\end{tabular}

17,043.6 Daltons and 16,899 Daltons, respectively. The study has demonstrated the species-specific variation in 2DE properties of buffalo and goat Mb's. Present study demonstrated the suitability of OFFGEL electrophoresis for determining the $\mathrm{p} I$ of $\mathrm{Mb}$ proteins. The study also reinforces the potential interaction between water buffalo and goat Mb's with a lipid derived aldehyde (HNE) via covalent modification of seven and nine histidine residues, respectively. The results suggest lower susceptibility of water buffalo $\mathrm{Mb}$ to the redox destabilizing effect of HNE compared to goat $\mathrm{Mb}$. Our findings provide explanation for the previously noted observation that more number of Mb-HIS adducts and increased alkylation of HIS residues will exacerbate the $\mathrm{Oxy}-\mathrm{Mb}$ oxidation.

\section{Methods}

\section{Materials}

Sephacryl S-200 HR and sodium hydrosulfite were obtained from Sigma-Aldrich chemicals Co., Sweden. The disposable PD-10 columns, IPG strips, DTT, Iodoacetamide, Acrylamide, Bis-acrylamide, Glycine, Methanol, Glacial Acetic acid, $\beta$-mercaptoenthanol and Coomassie blue, were obtained from GE Health Care. HNE was obtained from Cayman Chemical Company. Dialysis tubing was sourced from Spectrum laboratories, Inc. (Rancho Domingues, CA, USA). OFFGEL starter kit was procured from Agilent Technologies. All chemicals were of reagent grade or greater purity.

Isolation and purification of buffalo and goat myoglobins Buffalo and goat hearts procured from municipal abattoir, Chengicherla, Hyderabad, India were trimmed off fat and connective tissue, vacuum packaged and stored at-80 ${ }^{\circ} \mathrm{C}$ till extraction. Myoglobin $(\mathrm{Mb})$ was isolated from cardiac muscles [22]. Frozen cardiac muscle samples were chilled overnight in refrigerator, cut into small pieces and homogenized with buffer containing $10 \mathrm{mM}$ Tris- $\mathrm{HCl}$ with $1 \mathrm{mM}$ EDTA ( $\mathrm{pH}$ 8.0) and centrifuged at $5000 \mathrm{~g}$ for $10 \mathrm{~min}$ at $4{ }^{\circ} \mathrm{C}$. The supernatant was brought to $70 \%$ ammonium sulfate saturation and centrifuged at $18000 \mathrm{~g}$ for $20 \mathrm{~min} 4{ }^{\circ} \mathrm{C}$. The resulting supernatant was brought to $100 \%$ saturation with ammonium sulfate and centrifuged at $20000 \mathrm{~g}$ for $1 \mathrm{~h} 4{ }^{\circ} \mathrm{C}$. The precipitate was resuspended in homogenization buffer and dialyzed against ten volumes of dialysis buffer $(5 \mathrm{mM}$ Tris- $\mathrm{HCl}$ with $1 \mathrm{mM}$ EDTA, pH 8.0) for $24 \mathrm{~h}$, with buffer changes at every $8 \mathrm{~h}$ interval. The dialysate was filtered through $0.45 \mu \mathrm{m}$ syringe filter followed by and $0.22 \mu \mathrm{m}$ filter. The $3 \mathrm{~mL}$ filtrate with a protein concentration of approximately $10 \mathrm{mg} / \mathrm{mL}$ was loaded on to Sephacryl S-200 HR gel filtration column (Econo column, $1.5 \times$ $100 \mathrm{~cm}$, BIORAD) equilibrated with elution buffer (5 mM Tris- $\mathrm{HCl}$ with $1 \mathrm{mM}$ EDTA, $\mathrm{pH}$ 8.0) at a flow rate of $0.1 \mathrm{~mL} / \mathrm{min}$. Purified $\mathrm{Mb}$ fractions $(1 \mathrm{~mL})$ were collected and absorbance was measured at 280 and $540 \mathrm{~nm}$ using UV-VIS spectrophotometer (Model: UV-1700, PharmaSpec, SHIMADZU, Japan). To confirm the purity of $\mathrm{Mb}$, fractions were subjected to sodium dodecyl sulphate-polyacrylamide gel electrophoresis (SDSPAGE) and 2-dimensional gel electrophoresis (2DE).

\section{Isolation of sarcoplasmic proteome}

The sarcoplasmic proteome from buffalo and goat samples were extracted as described by Sentandreu et al. (2010) [32]. Frozen samples (1 g) were cut and homogenized in $10 \mathrm{~mL}$ cold extraction buffer $(50 \mathrm{mM}$ Tris, and $\mathrm{pH}$ 8.0). The homogenate was centrifuged at 10,000 g for $20 \mathrm{~min}$ at $4{ }^{\circ} \mathrm{C}$. The supernatant constituting the 
sarcoplasmic extract in which all soluble proteins were contained was filtered and used for $2 \mathrm{DE}$.

\section{Sodium dodecyl sulfate polyacrylamide gel electrophoresis}

SDS-PAGE analyses of buffalo and goat Mb fractions from different steps of purification were performed using the method of Laemmli (1970) under reducing conditions using a $4 \%$ stacking gel and $12 \%$ separating gel in midi-electrophoresis apparatus (Model: SE-600 Ruby; GE Healthcare, Uppsala, Sweeden) [33]. The current for each gel was maintained at $10 \mathrm{~mA}$. After separation, the proteins were stained with $0.1 \%(\mathrm{w} / \mathrm{v})$ coomassie brilliant blue R-250 in 50\% (v/v) methanol and 10\% (v/v) acetic acid, and destained with $40 \%$ methanol (v/v) and 10\% (v/ v) acetic acid. Destained images were scanned using Image Scanner-III, LabScan 6.0 (GE Healthcare, Uppsala, Sweeden) and IQTL calibration converter was used to obtain image.

\section{Two-dimensional gel electrophoresis and image analysis} Sarcoplasmic extract and gel-filtered (pure) Mb samples were passed through PD-10 desalting columns equilibrated with double distilled water to remove the salts. Later, protein concentration was determined using 2-D Quant Kit (GE Healthcare, USA) and 2DE was performed as described by Lametsch and Benedixen (2001) with few modifications [34]. The immobilized $\mathrm{pH}$ gradient (IPG) strips (Immobiline ${ }^{\oplus}$ drystrip, $11 \mathrm{~cm}, \mathrm{pH}$ range $3-10)$ were passively rehydrated in $200 \mu \mathrm{L}$ of myoglobin samples containing 750-800 $\mu$ g proteins for $12 \mathrm{~h}$. Rehydrated IPG strips were subjected to Iso-electric focusing (IEF) in a Ettan IPGPhor-3 (GE health care, Uppsala, Sweeden) gel apparatus at $18{ }^{\circ} \mathrm{C}$ for a total of $10800 \mathrm{Vh}$. Focused IPG strips were equilibrated in $6 \mathrm{M}$ urea, 20\% glycerol, 2\% SDS, $0.375 \mathrm{M}$ Tris ( $\mathrm{pH} \mathrm{8.8),} \mathrm{for} 15 \mathrm{~min}$ in $2 \%$ dithiothreitol (DTT) and 5\% iodoacetamide respectively. After equilibration, proteins were separated in the second dimension, with the SE 600 Ruby apparatus at $100 \mathrm{~V}$ with $60 \mathrm{~mA} /$ gel until tracking dye reached lower end of gel. The gel was removed and stained with colloidal Coomassie blue for $3 \mathrm{~h}$ followed by overnight destaining. Myoglobin samples from buffalo and goat were run under the same conditions and the three gels were produced for each.

Stained gels were scanned on an Image Scanner III using labscan 6.0 software. Spot detection and quantification were performed with Image Master Platinum7.0 software (GE Healthcare, Uppsala, Sweeden). The images were grouped into different groups according to required study and the intensity and area of individual spots were analyzed for comparative image analysis. For each spot in buffalo or goat Mb samples, spot quantity values in triplicate gels were averaged for statistical analysis. A spot was considered to be significant in differential abundance when it was associated with $P<0.05$.

\section{Determination of molecular mass using MALDI-TOF MS and protein identification through peptide mass finger- printing (PMF)}

Purified Mb was mixed 1:1 with 50\% sinapinic acid and the mixture was allowed to crystallize on the MALDI target plate for $10 \mathrm{~min}$. Protein molecular ions were analyzed in linear, positive ion mode using MALDI-TOF ULTRAFLEX III instrument (MALDI-TOF MS Bruker Daltonics, ULTRAFLEX III), using an acceleration voltage of $2.2 \mathrm{kV}$. The instrument was calibrated using lysozyme and beta-lactoglobulin as protein standards. The resulting spectra (from 1000 laser shots) were averaged, noise-smoothed, baseline-corrected, and analysed [12].

In-gel digestion of the myoglobin protein separated by 2DE was performed as described by Shevchenko et al. (2006) with slight modifications [35]. The PMF measured mass-to-charge ratio $(\mathrm{m} / z)$ values of peptides resulting from a protein digest form the basis for a characteristic fingerprint of the intact protein. Desalted peptide extracts $(0.3 \mu \mathrm{L})$ were spotted onto MALDI target plate with $0.3 \mu \mathrm{L}$ of $5 \mathrm{mg} / \mathrm{mL} \alpha$-cyano-4-hydroxycinnamic acid (Aldrich, St. Louis, MO, USA) in 50\% $\mathrm{CH}_{3} \mathrm{CN} / 50 \% 0.1 \%$ trifluoroacetic acid. Crystallized samples were washed with cold $0.1 \%$ trifluoroacetic acid and were analyzed in linear, positive ion mode on the MALDI-TOF ULTRAFLEX III instrument (MALDITOF MS Bruker Daltonics ULTRAFLEX III). The resulting spectra (from 600 laser shots) were averaged; noisesmoothed, baseline-corrected and further analysis was done with FLEX ANALYSIS SOFTWARE for obtaining the peptide mass fingerprint [36]. The masses obtained in the peptide mass fingerprint were submitted for MASCOT 2.2 search in NCBI database for identification of the protein.

\section{Determination of isoelectric point using OFFGEL electrophoresis}

Buffalo and goat $\mathrm{Mb}$ protein samples were fractionated by isoelectric focusing using an Agilent 3100 OFFGEL Fractionator (Agilent Technologies, Santa Clara, CA, USA), following manufacturer's instructions. Parts were assembled, Immobilised pH gradient (IPG) strips were rehydrated, and protein samples were diluted into the $1.25 \times$ OFFGEL stock solution as instructed in the Agilent Quick Start Guide. Mb proteins were focused based on their $\mathrm{p} I$ using two different $24 \mathrm{~cm}$ long IPG strips with a linear $\mathrm{pH}$ gradient ranging from 3.0 to 10.0 placed in the same tray following the Agilent method. A total of $0.5 \mathrm{mg}$ of $\mathrm{Mb}$ protein was loaded onto each IPG strip. At the end of the run, samples from each well were directly collected and subjected to SDS-PAGE analysis. 


\section{Reaction of buffalo and goat OxyMb's with HNE}

Buffalo $(0.15 \mathrm{mM})$ and goat $(0.075 \mathrm{mM})$ Oxy-Mb's were each combined with 1.0 and $0.5 \mathrm{mM}$ of 4-Hydroxy-2nonenal, respectively, at $37{ }^{\circ} \mathrm{C}, \mathrm{pH} 7.4$ and $25{ }^{\circ} \mathrm{C}$, $\mathrm{pH}$ 5.6, the typical $\mathrm{pH}$ in live animals and post-mortem muscles. These $\mathrm{Mb}$ concentrations were selected according to our earlier studies as they reflect the average $\mathrm{Mb}$ levels found in buffalo (5.0 $\mathrm{mg} \mathrm{Mb} / \mathrm{g}$ tissue) and goat (2.5 mg Mb/g tissue) meats. The molar ratio of $\mathrm{Mb}$ : aldehydes was maintained at 1:7 for all reactions [9]. Controls consisted of Oxy-Mb and a volume of ethanol equivalent to that used to deliver the HNE to the treatment mixture. During incubation, the control (Oxy-Mb + ethanol) and treatment (Oxy-Mb $+\mathrm{HNE})$ solutions were scanned spectrophotometrically from 650 to $450 \mathrm{~nm}$ using a UV-VIS spectrophotometer (Model: UV-1700, PharmaSpec, SHIMADZU, Japan). The blank contained only buffer $(10 \mathrm{mM}$ Tris- $\mathrm{HCl}$ with $1 \mathrm{mM}$ EDTA). Metmyoglobin formation was calculated using absorbance values at 503, 557, and $582 \mathrm{~nm}$ [37]. At the end of incubation, Mb-HNE mix was directly submitted for MALDI-TOF analysis, whereas for ESI-QTOF MS/ MS, the mix was subjected to SDS-PAGE and the gel bands were excised, digested and analysed.

\section{MALDI-TOF MS and ESI-QTOF MS/MS}

Native and HNE-treated buffalo and goat myoglobins (intact proteins) were analyzed by MALDI-TOF MS to detect changes in the total mass resulting from potential HNE adduction. One $\mathrm{mL}$ of the reaction solution was passed over a PD-10 desalting column calibrated with distilled water to remove unreacted 4-hydroxynonenal. Buffalo and goat $\mathrm{Mb}-\mathrm{HNE}$ adducts were detected using MALDI-TOF MS as explained earlier.

SDS-PAGE of native and HNE-treated buffalo and goat Mb's (after $3 \mathrm{~h}$ at $37^{\circ} \mathrm{C}$ and $\mathrm{pH}$ 7.4) was performed under reducing conditions using a midi-gel electrophoresis unit. Each band of native and HNE-treated buffalo and goat Mb's on Coomassie-stained gels were excised, destained and digested [35] with sequencing-grade trypsin at $37{ }^{\circ} \mathrm{C}$ for $18 \mathrm{~h}$. After digestion, the sample was vacuum dried and was dissolved in $50 \mu \mathrm{l}$ of $0.1 \%$ Formic acid. One $\mu \mathrm{l}$ of each of the samples were separated on the Nano-Acquity BEH C18 column $(100 \mu \mathrm{m}$ i.d. $\times 100 \mathrm{~mm})$ connected to WATERS nanoUPLC system for 150 min with $50 \%$ gradient of water $0.1 \%$ formic acid (buffer A) and $\mathrm{ACN}, 0.1 \%$ formic acid at a flow rate of $400 \mathrm{~nL} / \mathrm{min}$. The nano $\mathrm{LC}$ separated peptides were analysed for MS and MS/MS fragmentation on SYNAPT G2 WATERS nLC coupled QTOF mass spectrometer with ESI source.

The MS/MS spectra were acquired in data-dependent scanning mode with one full MS scan with a $m / z$ of 50-1000 followed by four MS/MS scans on the first four most intense ions with dynamic exclusion of previously selected precursors for a period of $1 \mathrm{~min}$. MS/MS spectra were matched to $\mathrm{Mb}$ database sequences using the protein database search software MASCOT search engine (http://www.matrixscience.com) with a parent ion tolerance of $2.5 \mathrm{amu}$ and fragment ion tolerance of $1 \mathrm{Da}$. Protein identification was done using the WATERS Protein Lynx Global Server (PLGS) v4.1 against the NCBI or UNIPROT database of Bubbalis bubbalis and Capra hircus Myoglobin. The raw data was obtained for the samples and was analysed in MASSLYNX (v4.1) using the BIOLYNX Tool and were checked for HNE modifications in the HISTIDINE sites of the respective myoglobin. The option Chordata (vertebrates and relatives) was selected as taxonomy restriction parameter. Electrophile adduction in several proteins has been identified successfully utilizing SALSA (Scoring Algorithm for Spectral Analysis).

\section{Statistical analysis}

Statistical analysis was performed with the analysis of variance (ANOVA) using SPSS (SPSS version 13.0 for windows; SPSS, Chicago, IL, USA). Least square means for F-tests were calculated by using Duncan's multiple range tests and were considered significant at $p<0.05$. The experimental design for evaluation of $\mathrm{Mb}$ oxidation study was a completely randomized design with three replicates $(n=3)$. The data for buffalo and goat were analyzed separately using two-way analysis of variance (ANOVA) option in SPSS and the differences among means were detected using the least significance difference (LSD) at a $5 \%$ level.

\section{Abbreviations}

2DE: Two-dimensional gel electrophoresis; ESI-QTOF MS/MS: Electrospray ionization quadrupole time-of-flight tandem mass spectrometry; HNE: 4Hydroxy-2-nonenal; IPG: Immobilized pH gradient; $\mathrm{m} / \mathrm{z}$ : Mass-to-charge ratio; MALDI-TOF-MS: Matrix-assisted laser desorption ionization-time of flight mass spectrometry; Mb: Myoglobin; MS: Mass spectrometry;

OxyMb: Oxymyoglobin; PMF: Peptide mass fingerprinting; SDS-PAGE: Sodium dodecyl sulfate polyacrylamide gel electrophoresis

\section{Acknowledgements}

The financial assistance from Department of Science and Technology (DST), Government of India (DST-FAST Track Project No. SR/FT/LS-149/2009) is acknowledged.

\section{Funding}

Department of Science and Technology (DST), Government of India provided funding to carry out this research project including design of the study and collection, analysis, and interpretation of data and in writing the manuscript through its grant DST-FAST Track Project No. SR/FT/LS-149/2009.

Availability of data and materials

Not applicable.

\section{Authors' contributions}

NM is responsible for the conception of the study data analysis and overall execution of the work; UK is responsible for myoglobin extraction, purification, SDS-PAGE characterization; PY performed the OFFGEL electrophoresis, Mb-HNE reaction and estimation of different $\mathrm{Mb}$ forms; $\mathrm{SR}$ is responsible for trypsin digestion, MALDI-TOF MS, PMF, Q-TOF MS/MS and all other MS related analysis; 
VK provided all the facilities and extended support for the study; NM and VK reviewed the data, compilation, manuscript writing, critical reviewing and submission; All authors wrote or contributed to the writing of the manuscript and approved the final version.

\section{Competing interests}

The authors have no known competing interests either financial or personal between themselves and others that might bias the work.

\section{Consent for publication}

Not applicable.

\section{Ethics approval and consent to participate}

Not applicable.

\section{Author details}

${ }^{1}$ National Research Centre on Meat, Chengicherla, Hyderabad, Telangana 500092, India. ${ }^{2}$ Proteomics Lab, National Centre for Cell Science, Pune 411007, India.

Received: 25 June 2016 Accepted: 3 November 2016

Published online: 16 November 2016

\section{References}

1. FAOSTAT. http://faostat.fao.org/site/291/default.aspx. 2013.

2. Naveena BM, Kiran M. Anim Front. 2014;4:18-24.

3. Webb EC, Casey NH, Simela L. Small Rum Res. 2005;60:153-66.

4. Naveena BM, Sen AR, Muthukumar M, Babji Y, Kondaiah N. Effects of salt and ammonium hydroxide on the quality of ground buffalo meat. Meat Sci. 2011:87:315-20

5. Dosi R, Di-Moro A, Chambery A, Colonna G, Costantini S, Geraci G, Parente A. Characterization and kinetics studies of water buffalo (Bubalus bubalis) myoglobin. Comp Biochem Phys Part B. 2006;145:230-8.

6. Babiker SA, El Khider IA, Shafie SA. Chemical composition and quality attributes of goat meat and lamb. Meat Sci. 1990;28:273-7.

7. Suman SP, Joseph P, Li S, Steinke L, Fontaine M. Primary structure of goat myoglobin. Meat Sci. 2009;82:456-60.

8. Suman SP, Joseph P. Myoglobin chemistry and meat color. The Ann Rev Food Sci Tech. 2013;4:79-99.

9. Faustman C, Liebler DC, McClure TD, Sun Q. alpha,beta-unsaturated aldehydes accelerate oxymyoglobin oxidation. J Agric Food Chem. 1999;47:3140-4.

10. Alderton AL, Faustman C, Liebler DC, Hill DW. Induction of redox instability of bovine myoglobin by adduction with 4-hydroxy-2-nonenal. Biochem. 2003;42:4398-405

11. Naveena BM, Faustman C, Tatiyaborwornatham N, Yin S, Ramanathan R, Mancini RA. Food Chem. 2010;122:836-40.

12. Suman SP, Faustman C, Stamer SL, Liebler DC. Proteomics of lipid oxidationinduced oxidation of porcine and bovine oxymyoglobins. Proteomics. 2007:7:628-40

13. Sakai T, Kuwazuru S, Yamauchi K, Uchida K. A lipid peroxidation-derived aldehyde, 4-hydroxy-2-nonenal and omega 6 fatty acids contents in meats. Biosci Biotech Biochem. 1995:59:1379-80.

14. Carini M, Aldini G, Facino RM. Mass spectrometry for detection of 4-hydroxy-trans-2-nonenal (HNE) adducts with peptides and proteins. Mass Spectrometry Rev. 2004;23:281-305

15. Petersen DR, Doorn JA. Reactions of 4-hydroxynonenal with proteins and cellular targets. Free Rad Biol Med. 2004;37:937-45.

16. Maheswarappa NB, Faustman C, Tatiyaborworntham N, Yin S, Ramanathan R, Mancini RA. Mass spectrometric characterization and redox instability of turkey and chicken myoglobins as induced by unsaturated aldehydes. J Agric Food Chem. 2009;57:8668-76.

17. Nair M, Suman SP, Li S, Joseph P, Beach CM. Lipid oxidation-induced oxidation in emu and ostrich myoglobins. Meat Sci. 2014;96:984-93.

18. Yin S, Faustman C, Tatiyaborwornatham N, Ramanathan R, Sun Q. The effects of HNE on ovine oxymyoglobin redox stability in a microsome model. Meat Sci. 2013;95:224-8.

19. Tatiyaborworntham N, Faustman C, Yin S, Ramanathan R, Mancini RA, Suman SP, Beach CM, et al. Redox instability and hemin loss of mutant sperm whale myoglobins induced by 4-hydroxynonenal in vitro. J Agric Food Chem. 2012;60:8473-83.
20. Canto ACVCS, Suman SP, Nair MN, Li S, Rentfrow G, Beach CM, Silva TJP, et al. Differential abundance of sarcoplasmic proteome explains animal effect on beef Longissimus lumborum color stability. Meat Sci. 2015;102:90-8.

21. Joseph P, Suman SP, Rentfrow G, Li S, Beach CM. Proteomics of musclespecific beef color stability. J Agric Food Chem. 2012;60:3196-203.

22. Faustman C, Phillips AL. Ch. F3 Unit F3.3. In: Current protocol in food analytical chemistry. 2001.

23. Wu W, Yu QQ, Fu Y, Tian XJ, Jia F, Li XM, Dai RT. J Proteomics. 2016;doi: 10. 1016/j.jprot.2015.10.027.

24. Han K, Dautrevaux M, Chaila X, Biserte G. The covalent structure of beef heart myoglobin. Eur J Biochem. 1970;16:465-71.

25. Han K, Tetaert D, Moschetto Y, Dautrevaux M, Kopeyan C. The covalent structure of sheep-heart myoglobin. Eur J Biochem. 1972;27:585-92.

26. Ros A, Faupel M, Mees M, Van Oostrum J, Ferrigno R, Reymond F, Michel P, et al. Protein purification by Off-Gel electrophoresis. Proteomics. 2002:2:151-6.

27. Zhu K, Zhao J, Lubman DM, Miller FR, Barder TJ. Protein pl shifts due to posttranslational modifications in the separation and characterization of proteins. Anal Chem. 2005;77:2745-55.

28. Faustman C, Sun Q, Mancini RA, Suman SP. Myoglobin and lipid oxidation interactions: mechanistic bases and control. Meat Sci. 2010:86:86-94.

29. Lynch MP, Faustman C. Effect of aldehyde lipid oxidation products on myoglobin. J Agric Food Chem. 2000:48:600-4.

30. Bolgar MS, Yang CY, Gaskell SJ. First direct evidence for lipid/protein conjugation in oxidized human low density lipoprotein. J Biol Chem. 1996;271:27999-8001.

31. Yin S, Faustman C, Tatiyaborwornatham N, Ramanathan R, Maheswarappa NB, Mancini RA, Joseph P, et al. Species-specific myoglobin oxidation. J Agric Food Chem. 2011;59:12198-203.

32. Sentandreu MA, Fraser PD, Halket J, Patel R, Bramley PM. A proteomic-based approach for detection of chicken in meat mixes. J Proteome Res. 2010;9:3374-83.

33. Laemmli UK. Cleavage of structural proteins during the assembly of the head of bacteriophage T4. Nature. 1970:227:680-5.

34. Lametsch R, Benedixen E. Proteome analysis applied to meat science: characterizing postmortem changes in porcine muscle. J Agric Food Chem. 2001:49:4531-7.

35. Shevchenko A, Tomas H, Halvis J, Olsen JV, Mann M. In-gel digestion for mass spectrometric characterization of proteins and proteomes. Nature Prot. 2006;1:2856-60

36. Padliya ND, Wood TD. Improved peptide mass fingerprinting matches via optimized sample preparation in MALDI mass spectrometry. Anal Chim Acta. 2008:627:162-8.

37. Tang J, Faustman C, Hoagland TA. J Food Sci. 2004;69:C717-20.

\section{Submit your next manuscript to BioMed Central and we will help you at every step:}

- We accept pre-submission inquiries

- Our selector tool helps you to find the most relevant journal

- We provide round the clock customer support

- Convenient online submission

- Thorough peer review

- Inclusion in PubMed and all major indexing services

- Maximum visibility for your research

Submit your manuscript at www.biomedcentral.com/submit 